\title{
Dams with Head Increaser Effect: Harnessing Potential and Kinetic Power from Rivers with Large Head and Flow Variation
}

\author{
Dr Julian David Hunt ${ }^{1}$ \\ Dr Edward Byers ${ }^{2}$ \\ Prof. Reinhard Prenner ${ }^{3}$ \\ Prof. Marcos Aurélio Vasconcelos de Freitas ${ }^{4}$
}

\begin{abstract}
There is an enormous untapped potential for hydropower generation in rivers with large
\end{abstract} head and high flow variation, currently not feasible for conventional hydropower dams. Conventional dams make use of the potential energy, but waste kinetic energy from spillage during periods of high flows. This article studies the possibility of harnessing energy from potential and kinetic energy from hydropower dams with large head and flow variation, analyses its potential, and shows possible technologies. Focus is given to a Moveable Hydro-Electric Power Plant (HEPP) system in which the turbine module can be adjusted according to the flow and water level in the river. During floods the exceeding flows can pass above and below the Moveable HEPP results in a sub-pressure environment after the turbine module, thereby reducing the dam's downstream head, increasing the pressure difference between the turbine inlet and outlet and the flow through the turbine, which increases the electricity generation of the dam. Dams with head increaser arrangement have been implemented in several dams in the 1930-1950s and now are regaining attention in Middle Europe. The main intention for its implementation is harnessing hydropower generation at run-of-river plants, with low-head, with a $20 \%$ to $30 \%$ cost reduction, lower flooded area at the dam site, the resulting evaporation and the impact on the aquatic fauna.

A case study was performed with the proposal of the Aripuanã Moveable HEPP in the Madeira River with a 26 meters height dam and a generation capacity of 1,400 MW. The increase in generation with the head increaser effect is as high as $21 \%$. The estimated potential for this technology in the Amazon region is $20 \mathrm{GW}$. Other potential locations are discussed in the article. Dams with head increaser effect have been successfully implemented and have the potential to become a major alternative for base load renewable energy in the future.

Keywords: Low-Head Hydropower, Hydrokinetics, Head Increasers, Ejector Turbine.

\footnotetext{
${ }^{1}$ Energy Program - International Institute for Applied Systems Analysis, hunt@iiasa.ac.at, +43 2236807675.

${ }^{2}$ Energy Program - International Institute for Applied Systems Analysis, byers@iiasa.ac.at, +43 2236807262.

${ }^{3}$ Institute of Hydraulic Engineering and Water Resources Management - TU Vienna, reinhard.prenner@tuwien.ac.at, +4315880122244.

${ }^{4}$ Energy Planning Programme - COPPE/UFRJ, mfreitas@ppe.ufrj.br, +55 2125628258.
} 
- Harnessing power from large head and flow variation rivers.

- Past and current experience of dams with head increaser effect.

- Case study for a Moveable HEPP system in the Amazon River.

- Energy potential with this technology is estimated to be $20 \mathrm{GW}$ in the Amazon Region.

\section{Introduction}

Hydropower is the main renewable technology for electricity generation in the world and has reached an installed capacity of 1,000 GW in 2014 [1]. Hydropower is a well-established technology that brings benefits to society, such as long-term, renewable, low-carbon electricity generation, water storage [2, 3] and flood control [4]. However, it has a high capital cost [5], may flood large areas, interrupts the course of a river, obstructs the natural habitat of the river's flora and fauna and causes social impact $[6,7]$.

In order to contribute to the global transition from fossil to renewable energy sources several countries are now focusing on power generation from low-head hydropower plants [8]. As low-head power stations are often designed to cover only a pre-determined base load supply, economic comparisons with fossil or nuclear power plants, have often favoured the latter alternatives [9]. Thus, it is not surprising that there is still an immense unexploited potential for low-head hydropower available today, despite over a century of water turbine production. Important aspects in this context are how to maximize the exploitation of the hydraulic power available at a new power plant site with considerable economic gains and respect both society and the environment. An example of a vast, low-head generation potential exists in the Amazon region in Brazil.

Potential energy from the Madeira River, in the Amazon Basin, has been recently harnessed using Bulb turbines in the Santo Antonio and Jirau Dams. These dams take into account the changes in water level and flow to optimize generation. During the dry season, the river flow is lower and the generation head is higher. During the rainy season, the river flow increases and the generation head reduces. In practice, the generation head in Santo Antonio dam varies from 13 to 25 meters [10]. This combination of higher head and lower flow during the dry period and lower head and higher flow during the wet period allows the plant to operate with a $60 \%$ capacity factor, making the operation of these dams economically viable. Figure 1 (a) presents the axial view of the Bulb turbine in the Santo Antônio Dam and Figure 1 (b) shows the axial view of the dam's spillway. As shown in Figure 1 (c), the conventional Bulb powerhouses are positioned in 


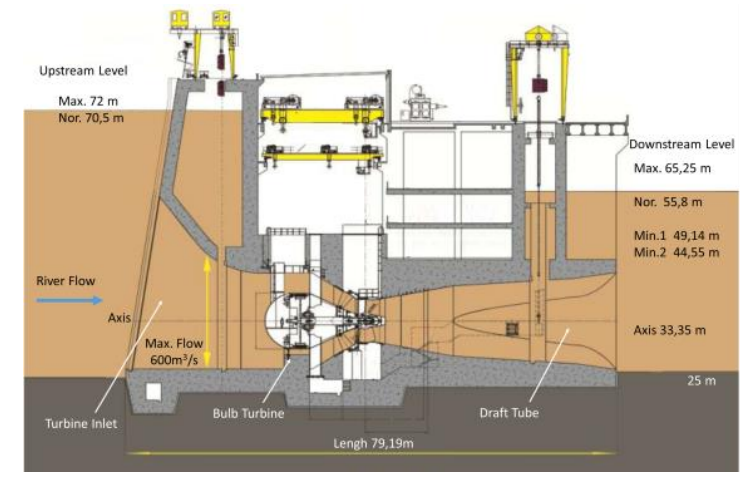

(a)

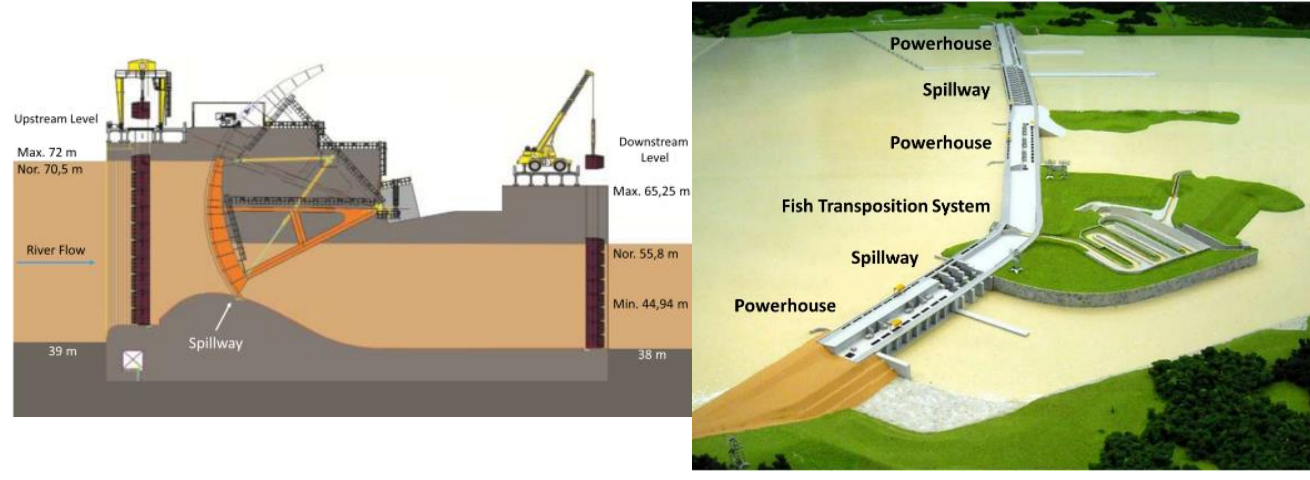

(b)

(c)
74

Figure 1: Longitudinal view of the Santo Antônio Dam (a) Bulb turbine and (b) spillway, and (c) overview of the Santo Antônio Dam [10].

Currently other alternatives are being explored to harness kinetic energy from rivers with hydrokinetic technology $[17,18,19]$. Different types of technologies have been developed for this purpose, such as horizontal axis hydrokinetic turbines [20, 21, 22, 23], vertical axis current turbines [24, 25, 26], portable micro-hydrokinetic turbines [27], hydrokinetic energy for smart grid operation [28] and hydrokinetic turbines downstream an existing dam [29, 30]. Hydrokinetic turbines downstream an existing dam would only generate electricity at full capacity when there is water spilled from the dams upstream, which result in a reduced capacity factor. Alternatively, the number of turbines in the dam can be increased so that the water spilled over the dam is reduced. This would result in an overall higher electricity generation potential than a hydrokinetic turbine downstream of a dam. A review of the costs and environmental impact of the hydrokinetic technology can be seen in $[31,32]$. The number of research papers studying hydrokinetic turbines and the number of companies investing in this technology is increasing fast, which is improving their designs and reducing costs.

The main challenge to make a low-head hydropower project (using potential energy) or a hydrokinetic project (using kinetic energy) viable is to increase the capacity factor of the plant as a whole (turbines, generators, substations, transmission lines, etc.).

An interesting hydropower concept that can harness both the potential and kinetic energy from a river, increasing the overall capacity factor of the plant is the Head Increaser Dam (HID). The concept was firstly experimented in 1905 and several prototypes were implemented from the 1930s to the 1950s [33]. With the increase in coal and other fossil fuel generation sources, further research and implementation of HID were reduced. It regained some momentum with the fuel crisis in the 70-80s. Nowadays, with the global interest of moving into a more renewable 
electricity grid, head increaser dams has been successfully implemented and has the potential to become a major source for base load renewable energy in the future.

This paper is divided into seven sections. Section 2 presents the head increaser technology and three different approaches for head increaser dams, these are the draft tube ejector, backwater suppressor and the Moveable HEPP. Section 3 presents the potential for head increaser dams in the world and in the Amazon river. Section 4 explains how the head increaser methodology works, presents the displays the yearly operation of a Moveable HEPP prototype and the equations used to estimate the gains from the head increaser effect. Section 5 presents the results of the investigated Aripuanã Moveable HEPP on the Madeira River. Section 6 discusses the benefits and challenges of head increaser dams and Section 7 concludes the paper.

\section{Dams with Head Increaser Effect}

The common physical principle underlying dams with head increaser effect is to mix the excess flow (spilled flow), or part of it, with the flow leaving the draft tube and, thus, transmit part of the kinetic energy inherent in the high velocity spilled water to the slow discharge leaving the turbine runner. The acceleration, thus, obtained is accompanied by a corresponding reduction in the pressure prevailing in the draft-tube exit. The effect may be considered equivalent to lowering the tailwater level, i.e. to increase the effective head of dam [34]. More details on the head increaser effect is presented in Section 3.

Currently, HID has been applied due to increasing environmental restrictions to new hydropower development. This is because, these types of dams are low-head plants, which require less flooded area and result in less environmental and social impact during construction and operation [35]. Mention must be made of the past debate on the submersible plant with the head increaser effect, which has received widespread attention in the past [34]. In spite of the many advantages listed in Table 1, application of the head increaser effect in high-capacity, low-head run-of-the-river dams has failed to come about for the reasons also mentioned in Table 1. More details on these characteristics are explained in the following references and throughout the paper. Comprehensive reviews on the technology were published on $[33,34,36]$.

Table 1: Review of the benefits and challenges of head increaser dams.

\begin{tabular}{l|l|}
\multicolumn{1}{c|}{ Benefits } & \multicolumn{1}{c|}{ Challenges } \\
$\begin{array}{l}\text { Combines the utilization of both potential energy, when the generation head is } \\
\text { high and kinetic energy, when the river flow rate is high, of the river for } \\
\text { electricity generation [33]. }\end{array}$ & $\begin{array}{l}\text { Reduces the overall hydropower } \\
\text { potential of the river. This is } \\
\text { because of the large spilled flow } \\
\text { allowed in the dam design }\end{array}$ \\
$\begin{array}{l}\text { Thergy from the river in the same hydropower project, increases the capacity } \\
\text { factor of the plant, (i.e. turbines, generators, sub-station and transmission lines), } \\
\text { which increases the economic viability of the project. }\end{array}$ & \\
\hline
\end{tabular}


Increased economic viability of low-head hydropower dams. HID, for dams up to $10 \mathrm{~m}$, are 15 to $20 \%$ cheaper than conventional low-head dams for the same final generation output [34]. The higher the dam height the smaller the cost difference.

A challenge in the operation of low-head plants is the reduction of generation capacity during flood periods. HID plants use the excess water to increase its generation, reducing the impact of floods in power generation [37].

Compactness of the dam, results in less concrete and cheaper dams [9]. This is because the spillway and the turbine are positioned in the same vertical axis and because the dam has a similar length to the river during high flow rates.

Due to the vertical arrangement of the turbines and spillway, favourable flow conditions are ensured in the entire width of the river, with uniform flow to the turbines [34].

Straight runner passages, as is Bulb turbines, required a narrower substructure than in conventional installations (with spiral casing and elbow-type draft tube) [34].

The flow passes through the runner almost without changing direction, thus reducing hydraulic losses [34].

The absence of the involved spiral casing and of the elbow type draft tube, shuttering and concreting work is simplified, and therefore construction time can be shortened [34].

As compared to the spiral casing and elbow type draft-tube settings, a gain in foundation depth can be achieved in some instances [34].

As compared to plants having deep-sill movable gates, the weight of steel structures is significantly reduced, and even hoist and cranes may be of less weight as compared with those of the block power station [34].

Head increaser chutes can be arranged to serve the purpose of ice release mechanism in dams during the winter [34].

HID dams can be implemented in a modular approach, reducing construction costs and time [38], and reducing environmental and social impacts during construction.
Only a small share of the kinetic energy (up to $30-40 \%$ ) from the water spilled is harnessed through the turbine. Thus, this dam is intended to be applied in locations where harnessing the majority of the hydropower potential is not economically viable or due to social or environmental restrictions [34].

Water-sealing problems are more numerous. These problems, however, can be considered as solved without noticeable effects on investment costs [34].

Low-head dams are usually expensive.

The permissible runner diameter is smaller due to the vertical position of the spillway and the turbine, limiting the turbine output. The lower the head, the smaller the runner diameters must be used, if exceedingly deep and expensive foundation work is to be avoided. However, the larger the runner diameters the better [34].

The division of the plant output into several small units can lower over-all efficiency [34].
128

\subsection{Types of Dams with Head Increaser Effect}

\subsubsection{Draft Tube Ejectors}

Several types and designs of head increaser dams have been developed for the utilization of the wasted discharges that exceeds the plant capacity. These were divided into three major types and named Ejector Draft Tube, Backwater Suppressor, Moveable HEPP.

In draft tube ejectors, the head increaser effect is obtained by ejecting the excess discharge into the draft tube. The resulting high velocity jet produces a lower pressure at the turbine exit, resulting in higher power output capability under heads reduced by as much as $20 \%$. Several approaches for draft tube ejectors have been proposed, for example, the Moody Ejector Turbine [37] and the Tefft Tube [36], which are equipped with a gate to allow excess flow to enter the low-pressure draft tube throat during flood periods. Figure 2 presents a sketch of a draft tube 
ejector. Clemens Herschel, the inventor of the venturi meter, designed a turbine with head increaser effect where the discharge end, of a vertical, conical draft tube, was inserted into the throat of a large, horizontal, venturi meter [39].

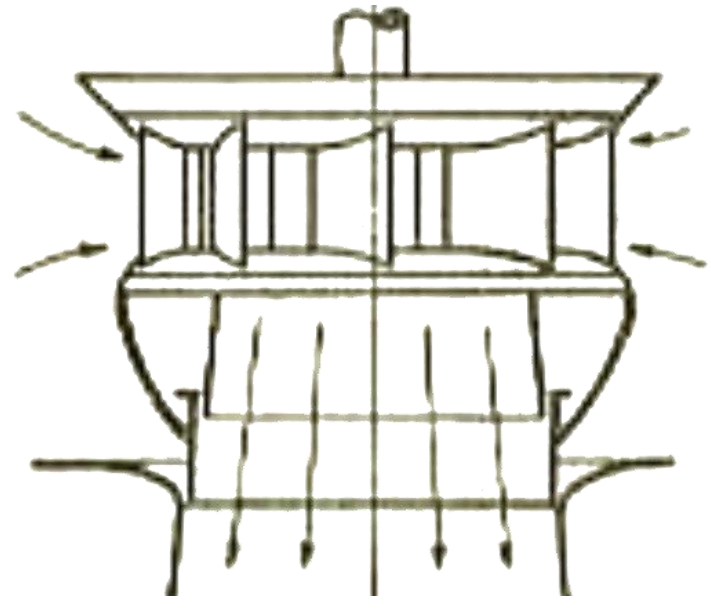

(a)

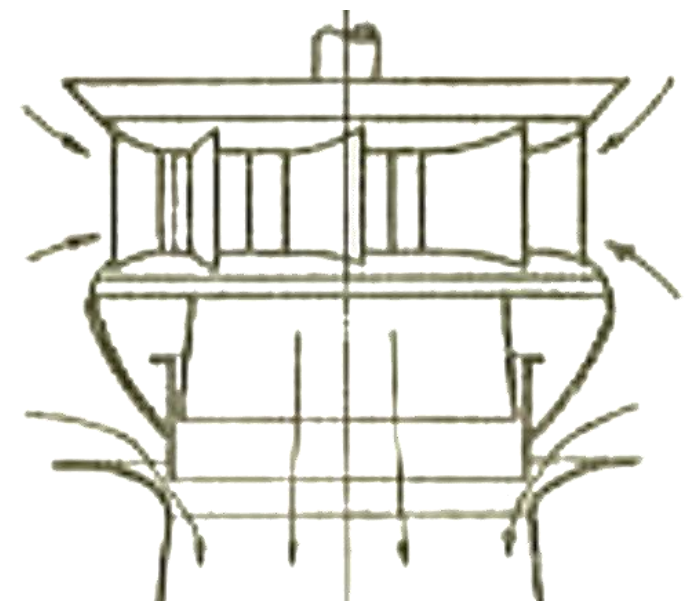

(b)

Figure 2: Draft tube ejector (a) without and (b) with head increaser effect [37].

Examples of draft tube ejectors were applied in Hodenpyl power station, USA, utilizing Telt type ejectors at a head of $19.5 \mathrm{~m}$, and $18 \mathrm{MW}$ capacity [40, 36, 41]. A similar arrangement has been adopted for the Alcona station, USA, delivering $8 \mathrm{MW}$ under a head of $12.3 \mathrm{~m}$. An experimental turbine designed by Henry Ford and Thomas Edison on the Henry Ford farms was capable of developing its rated power at one-half the normal head [42]. The concept here was a discharge accelerator built in the tailrace, which utilized excess flow [36]. After some experience, the costs of the realization of draft tube ejectors proved to be prohibitive and the use was discontinued [34].

\subsubsection{Dams with Backwater Suppressor Effect}

Dams with backwater suppressor effect have also been named as Thurlow backwater suppressor dams, weir power stations or submerged power stations [43, 44, 34, 45]. With closely spaced units, the excess discharge is released through spillway chutes arranged over the draft tubes, as shown in Figure 3 (b). The main contribution of this head increaser arrangement is to remove the accumulation of backwater from over the draft tube discharge to increase the effective head on the turbine by the removal of negative, static, backwater head.

A comparative example of a dam with backwater suppressor effect (Figure 3 (b)) with a conventional block hydropower dam (Figure 3 (a)) was proposed by Escher Wyss in 1973 for the construction of the Salto Grande Dam between Uruguay and Argentina. The total savings achieved by the alternative design, including turbine, generator, switchgear, civil engineering 
173 (concrete and excavation) and weir equipment, were greater than the whole cost of the hydraulic

174 installation, including their erection. A maximum flow of $57,000 \mathrm{~m}^{3} / \mathrm{s}$ was assumed for the

175 dimensioning of weirs and bottom outlets. The results of this comparative study are summarized

176 in Figure 3 and Table 2 [9].

177 Table 2: Comparative study for Salto Grande Dam between Uruguay and Argentina [9].

\begin{tabular}{|l|c|c|}
\hline Hydroelectric concept & $\begin{array}{c}\text { Vertical double regulated } \\
\text { Kaplan Turbine with } \\
\text { umbrella type generator } \\
\text { Block power station }\end{array}$ & $\begin{array}{c}\text { Horizontal double-regulated } \\
\text { Straight flow turbine with } \\
\text { ring generator }\end{array}$ \\
\hline Layout concept & 12 & 24 \\
\hline Number of machines & 8,500 & 5,700 \\
\hline Runner diameter $(\mathrm{mm})$ & 75 & 125 \\
\hline Speed (rpm) & 32 & 32 \\
\hline Head $(\mathrm{m})$ & 135 & 75 \\
\hline Unit output (MW) & 1,620 & 1,800 \\
\hline Total output $(\mathrm{MW})$ & 833 & 676 \\
\hline Width $(\mathrm{m})$ & 73 & 55 \\
\hline Length $(\mathrm{m})$ & 59.25 & 41 \\
\hline Height $(\mathrm{m})$ & -20.25 & -17.50 \\
\hline Lowest excavation level $(\mathrm{m})$ & $1,377,000$ & 820,000 \\
\hline Excavated volume $\left(\mathrm{m}^{3}\right)$ & $1,348,000$ & 745,000 \\
\hline Volume of concrete $\left(\mathrm{m}^{3}\right)$ & & \\
\hline
\end{tabular}

178
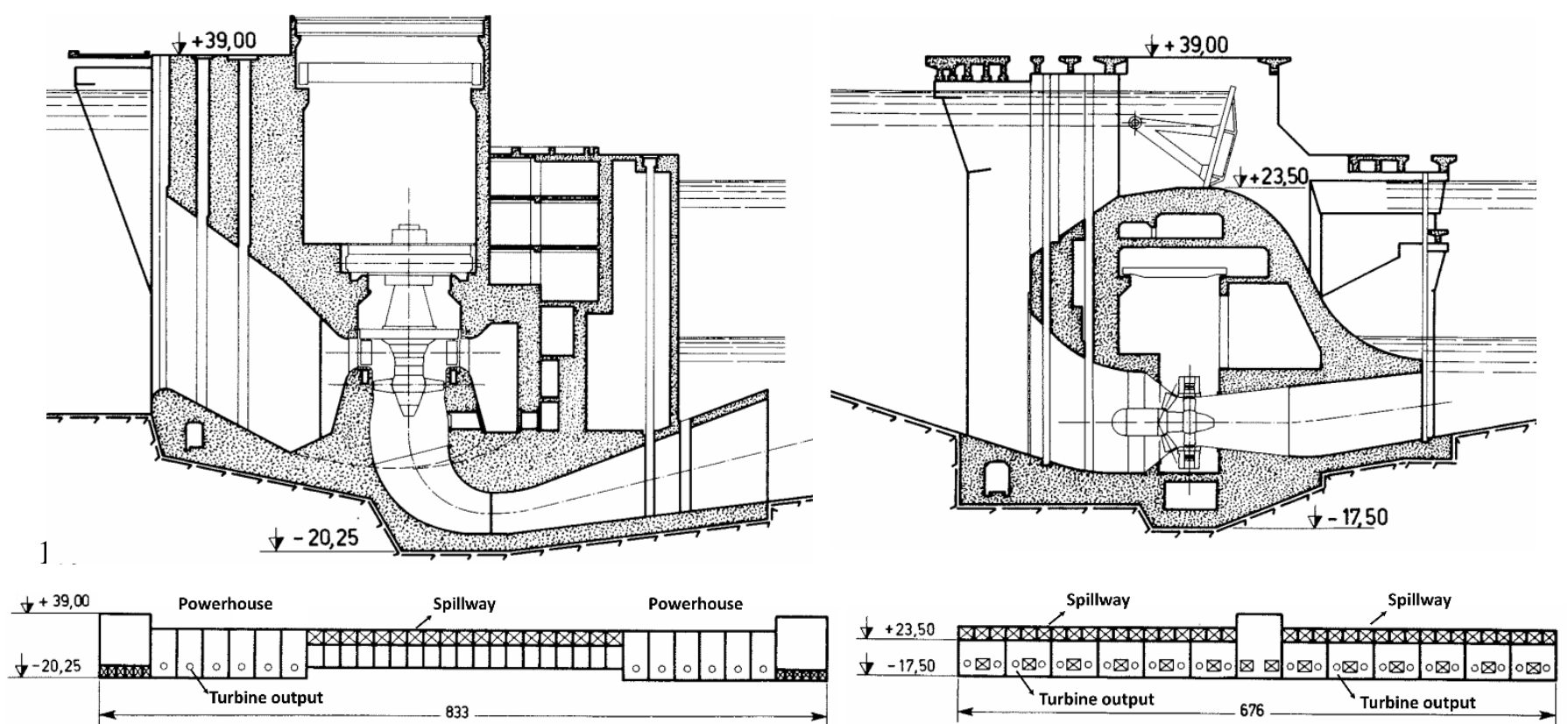

181

182

183

184 Other examples of backwater suppressor dams are Kembs (Rhine, France), Mitchell

185 (USA) [36], Kiev (Dnepr, Ukraine), Rott-Freilanssing (Saalach, Austro-German border), Roscin

186 (Poland), Steinbach (Iller River, Germany), and Volgograd (Volga, Russia), which when

(a) (b)

Figure 3: Comparative study for Salto Grande Dam between Uruguay and Argentina with a (a)

block power station design and (b) a weir power station design [9]. 
constructed it was the largest hydropower station in the world with a capacity of 2,530 MW [34]. Apart from the head-increasing effect, submersible dams were applied in wartime in Germany for air defence considerations since the station built without the prominent machine hall was thought to be less conspicuous from above. The backwater suppressor dam has proven to be the most successful and most applied head increasers approach in the past [34].

\subsubsection{Moveable Hydro-Electric Power Plant (HEPP)}

The Moveable HEPP concept is new and has been implemented mainly in Germany and

196 Austria and Switzerland [46]. The current implementation of this head increaser type of dam has

197 been led by the dissemination of the Hydro-Energie Roth turbine as presented in [47]. The system

198 consists of Kaplan/Bulb turbines inside a metal container with rectangular shape as presented in

199 Figure 4 (a). The system can maintain a high generation capacity factor, because during periods

200 of low flow rate, the level of the river downstream is low and, thus, the generation head is high.

201 This contributes to a high potential energy for hydropower generation. During period of high river

202 flow, the level of the river downstream increases, which reduces the generation head. However,

203 the increased flow of the river increases the kinetic energy, which is harnessed in detriment of the

204 potential energy. Kinetic energy yield through the head increaser effect on a Moveable HEPP

205 system on the Ilm River at high water flows reached a level up to 23\% [48]. The Stadtwehr power

206 station in the Ybbs River, allows an efficiency increase of $20 \%$ to $30 \%$, compared to conventional

207 low-head dams, due to the head increaser effect on an average of 80 days (periods of high river

208 flows) [49]. In the Offenburg, Moveable HEPP system, with $0.45 \mathrm{MW}$, the kinetic energy yield

209 through the head increaser effect increases generation up to $45 \%$ in high river flow rates [48].

210 Figure 4 (b) presents the representation of the Offenburg, Moveable HEPP at the Kinzig River

211 and Figure 4 (c) presents a prototype picture of the same plant.

(a)

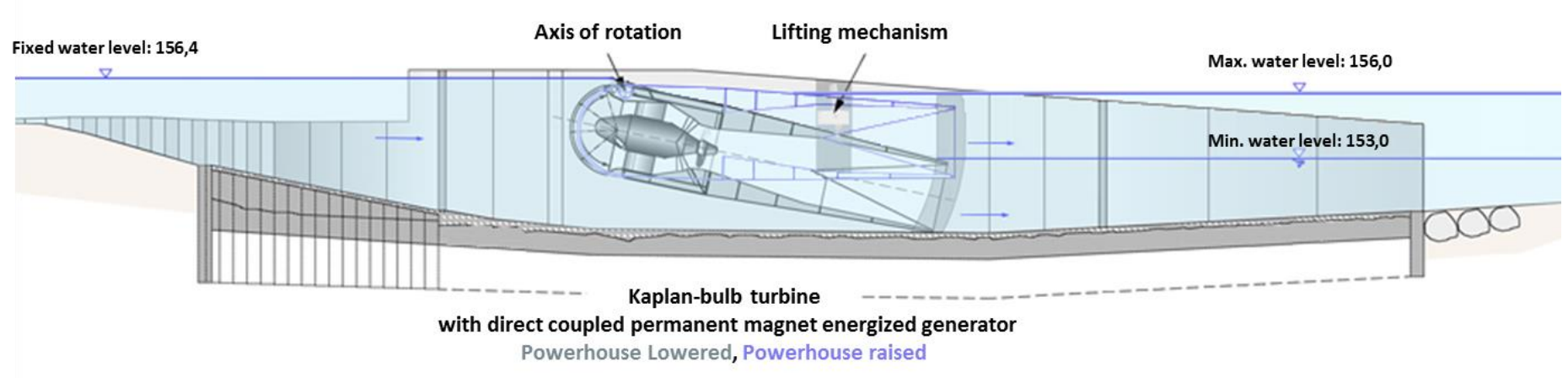


(b)

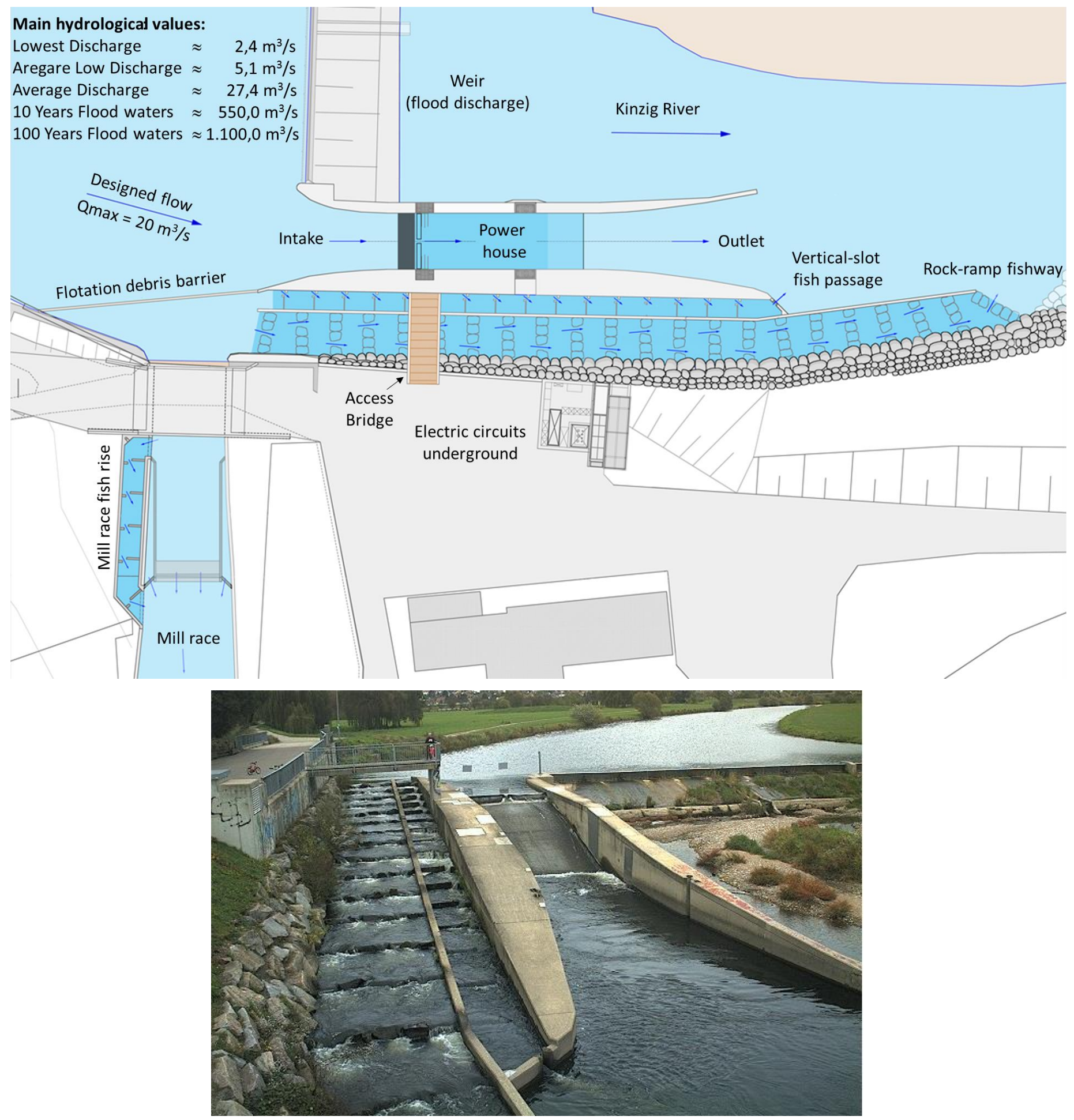

212 Figure 4: Offenburg, Moveable HEPP (a) longitudinal section and (b) layout, and (c) prototype picture $[50,51]$.

214 Environmental regulations typically state that fish must be able to safely pass through 215 hydropower plants. Conventional hydropower plants, however, can only comply with these 216 regulations by constructing additional expensive structures. With Moveable HEPP system, fish 217 are free to pass above and below the turbine [46]. 
219 Upper-Rhine region. The lifting of the turbine module at times of higher flows allows part of the

220 water and with it the bedload (gravel) to flow beneath the turbine module and also allows the fish

221 to pass under and over the power module on the upstream-downstream direction. This is beneficial

222 because moments of high flow rate, are also most relevant for sediment transport [46]. For the

223 fish to move on the downstream-upstream direction, a fish ladder is required. This technology has

224 received the award for best environmental project in 2011 from the International Commission for

225 the Protection of the Danube River [52] and from the EU-Life program [46, 53]. It also won the

226 'NEO2010 - Innovationspreis der TechnologieRegion Karlsruhe' and the 'Umwelttechnikpreis

227 Baden-Württemberg 2011', environmental awards for outstanding and innovative products in

228 environmental technology [46]. Other publications discuss the benefits of the moveable HEPP for

229 fish migration $[54,35,55,56]$.

230 The lack of costs for compensatory measures for managing floods or the transfer of 231 riverbed sediments are important economic benefits of the technology. The project calculated that

232 HEPP's greater efficiency could lead to savings of $16 \%$ in comparison with conventional plants 233 and $11 \%$ higher returns with electricity sales. Combining these factors led the Moveable HEPP 234 planners to estimate that its technology could increase the ratio of raw profit per investment sum 235 by more than $40 \%$ (from $5.18 \%$ to $7.36 \%$ ) [46]. Another economic benefit is the modular 236 approach of construction, which shortens construction time and reduce social and environmental 237 impact. The system is delivered in two pieces and both can be mounted in parallel [46]. Additional 238 cost reductions would result from increased production of the turbine modules and gains in scale.

239 For more information on other suppliers of the Moveable HEPP system refer to [57, 58,

240 59], for other projects refer to [60, 61, 62]. Recent studies of the potential of the Moveable HEPP 241 are presented in [63, 64] and recent laboratory experiments are presented in [27, 8, 65]. The main 242 benefits from this technology are described in Table 3. Due to its modularity, lower costs and 243 environmental friendliness, the Moveable HEPP design has being the selected head increaser 244 technology to be implemented in the case study of this paper.

Table 3: Main benefits of the Moveable HEPP [52, 57].

Main benefits of the Moveable HEPP

\begin{tabular}{|l|l|}
\hline $\begin{array}{l}\text { Viable alternative to generate electricity with heads } \\
\text { lower than 5 meters. }\end{array}$ & No sedimentation of impounded and discharge sections. \\
\hline $\begin{array}{l}\text { Environmental regulations are requiring upstream and } \\
\text { downstream fish migration through a dam. }\end{array}$ & $\begin{array}{l}\text { No lubricant emissions on the water body due to the use } \\
\text { of permanent magnet generators instead of gears. }\end{array}$ \\
\hline $\begin{array}{l}\text { Powerhouse can be lifted in order to allow direct } \\
\text { sediment transport. No additional sediment trap or } \\
\text { similar installations are required. }\end{array}$ & $\begin{array}{l}\text { High overall efficiency due to optimized hydraulic } \\
\text { conditions and choice of machine components. }\end{array}$ \\
\hline Nearly invisible because constantly overflowed. & Short construction time and low construction costs. \\
\hline $\begin{array}{l}\text { Allows downstream migration of fish via the } \\
\text { powerhouse and in addition enable transport of debris } \\
\text { and driftwood. }\end{array}$ & $\begin{array}{l}\text { Enable economic use of low drop heights for } \\
\text { hydropower production. }\end{array}$ \\
\hline
\end{tabular}




\begin{tabular}{|l|l|}
\hline $\begin{array}{l}\text { No deterioration of the river cross-section in case of } \\
\text { flood events. }\end{array}$ & $\begin{array}{l}\text { High energy recovery due to the use of ejector effect at } \\
\text { the end of the draft tube. }\end{array}$ \\
\hline $\begin{array}{l}\text { Making use of high flows for increased energy } \\
\text { generation requirements. }\end{array}$ & $\begin{array}{l}\text { Robust, long-life technology requiring low } \\
\text { maintenance. }\end{array}$ \\
\hline $\begin{array}{l}\text { Allowing downstream migration of fish and other } \\
\text { aquatic species, during high flows. }\end{array}$ & $\begin{array}{l}\text { Short construction time and low construction costs due } \\
\text { to simple construction technique. }\end{array}$ \\
\hline $\begin{array}{l}\text { Up to 30\% reduced construction costs for same annual } \\
\text { production. }\end{array}$ & \\
\hline
\end{tabular}

246

247 3. Large Head and Flow Variation Rivers Energy Potential

Globally, the seasonality of river flows vary substantially, which has important

250 implications to the suitability of conventional hydropower. The more seasonal the flow, the worst

251 it is for conventional hydropower plants. However, hydropower developments in rivers with

252 highly seasonal flows and level variation can be viable with Head Increaser Dams as it is

253 explained in this paper.

254 One way to assess the potential for Head Increaser Dams at the global scale is by 255 comparison with a seasonality index, the coefficient of variation of mean monthly runoff, shown

256 in Figure 5. The data derive from the Lund-Postdam-Jena managed Land model [66], a global

257 dynamic vegetation and terrestrial water cycle model forced with five climate models at $0.5^{\circ}$ grid

258 resolution [67]. Whilst most of Europe and North America have low runoff seasonality, parts of

259 South America, sub-Saharan Africa and Asia have high seasonality with potential for

260 implementation of HIDs. The Zambezi basin in southeast Africa, in particular, could be suitable

261 due to high runoff in the tributary areas off the main river.

262 Another important aspect of the implementation of HID is the variation of river levels.

263 This data is not available on a worldwide scale for a wide analysis, such as in Figure 5. Some

264 world locations with seasonal flow (seasonality value higher than 0.75 ) and high river level

265 variation are shown as follows, with a reference presenting its river level variation: Zambezi river

266 [68], Yangtze river in China [69], Indus river in Pakistan [70], Ganges and Brahmaputra rivers in

267 India [71], Orinoco river in Venezuela [70], Paraguay river in Paraguay [70] and the Amazon

268 river in Brazil [72]. 

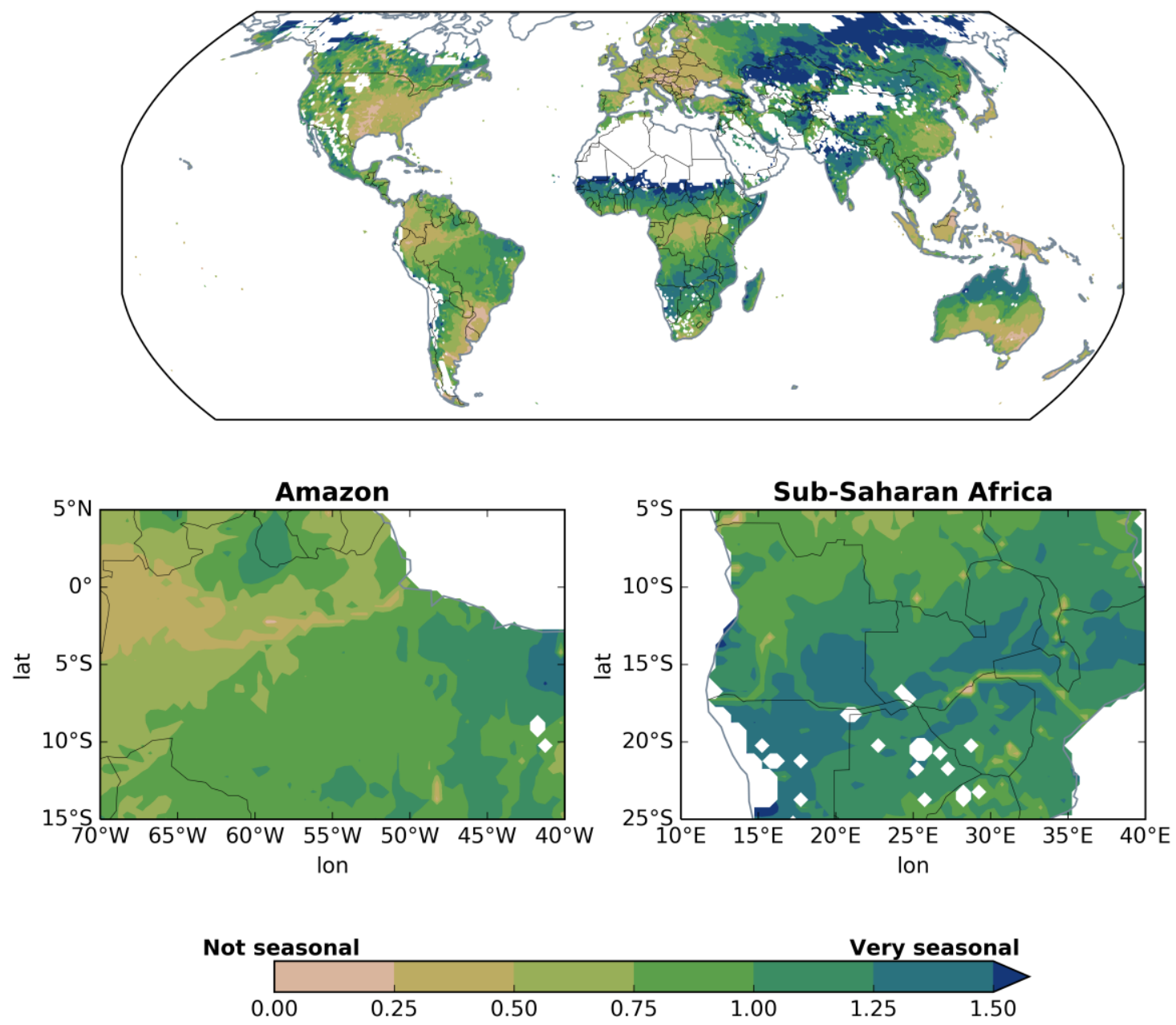

Figure 5. Global map of runoff seasonality index with zoom in on the Amazon and Southern

Africa regions. Hyper-arid areas have been masked.

\subsection{Amazon River Potential}

Brazil has a large hydropower potential, especially in the Amazon region with low-head dams. The rivers in the Amazon watershed have high flow and level variability, as shown in Figure 6. This is because, during the wet period, the rainfall increases considerably and the altitude of the river above sea level is low. For the water flow to the ocean, a minimum head difference is required. For example, in the Madeira River, close to the border with Bolivia, the minimum height of the river is 95 meters above sea level and the distance to the ocean is around $2.400 \mathrm{~km}$. This results in an insignificant slope to drain the water. Thus, during the wet period, the level of the river has to increase around 15 meters to increase the slope and flow area so that the water can drain into the ocean.

This large river level variation is appropriate for low-head hydropower generation making use of the head increased effect. This is because potential energy can be used to harness hydropower during the dry period and kinetic energy during the wet period. In addition, a dam 
can be built with its level a few meters higher than the yearly maximum river level. This way, the dam would flood an area slightly larger than the area it is already flooding every year during the wet period. Figure 6 shows that the average river level variation in the Amazon Regions reaches 18 meters. The rivers with the highest yearly level and flow variation, in a decreasing order are: the Purus, Solimões, Juruá, Madeira, Negro, Tapajós, Araguaia and Xingú Rivers.

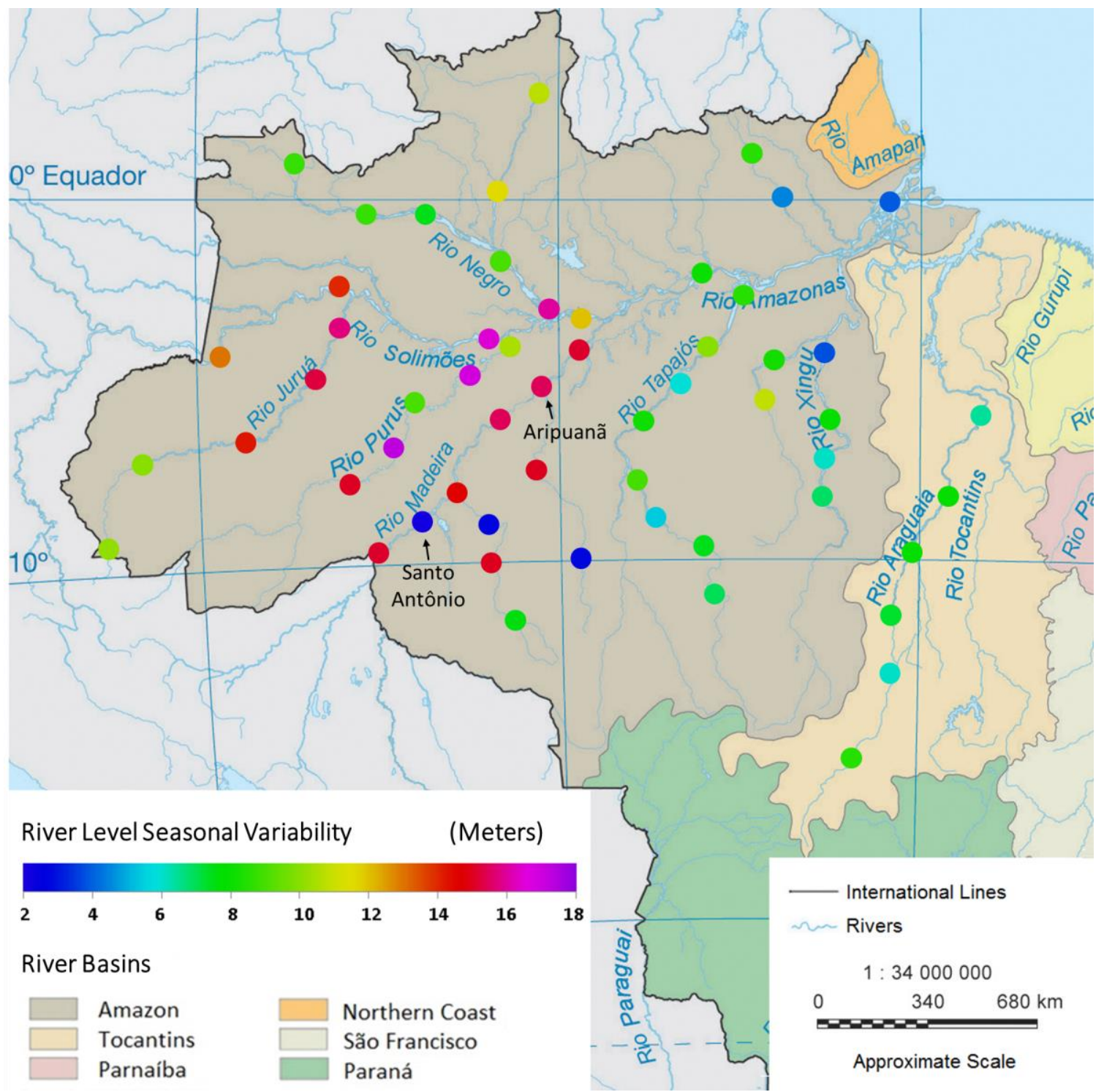

Figure 6: Average river level seasonal variation in the Amazon and Tocantins basins [72].

\section{Methodology}

The main physical concept exploited by this technology is the venturi effect as presented in Figure 7. The venturi effect establishes that if the initial velocity of a fluid $\left(\mathrm{V}_{1}\right)$, with a pressure $P_{1}$, increases to $V_{2}$, the pressure will reduce to $P_{2}$ according to the equation shown in Figure 7 . 


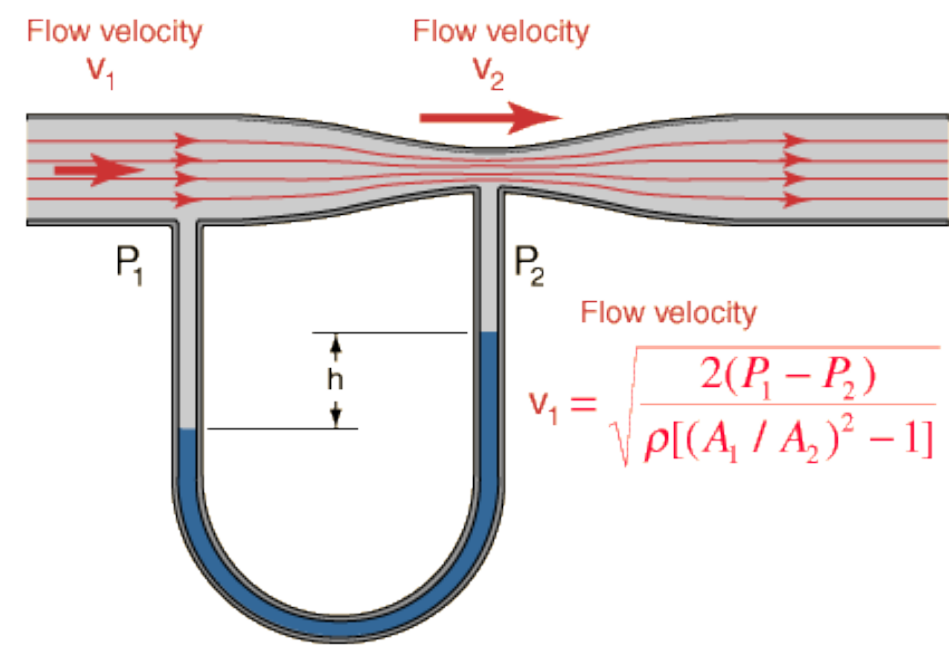

Figure 7: Sketch of the venturi effect [73].

Aside from changing and measuring the velocity in fluids, the venturi effect is used for mixing air and flammable gas in stoves, airbrushes, water aspirators that produce a partial vacuum using the kinetic energy from the faucet water pressure, atomizers that disperse perfume or spray paint, wine aerators used to infuse air into wine as it is poured into a glass, compressed air industrial vacuum cleaners, venturi scrubbers used to clean flue gas emissions, ventilators, airfoils moving close to the ground (ground effect [74]) amongst many other applications.

Unlike conventional Bulb hydropower plants, the Moveable HEPP turbine module servers both for electricity generation and to control the spilled flow in the river. This arrangement considerably reduces the costs of building the dam due to the lack of a purposely built spillway, as in conventional dams. During months of low river flow and level, the turbine module leans on the riverbed obstructing the flow of the river, as shown in Figure 9 (a). During months of high river flow and level, the turbine module is positioned horizontally, allowing the flow to pass below and above the turbine module as shown in Figure 9 (c).

In the Moveable HEPP dam, the level of the upstream reservoir operates as a run-of-theriver dam, i.e. the level stays constant throughout the year. The by-passed water with a high velocity ( $\mathrm{V}_{3}$ in Figure 8 ) creates a low-pressure area after the turbine module $\left(\mathrm{P}_{3}\right)$. This reduces the pressure at the turbine module outlet $\left(\mathrm{P}_{2}\right)$. The higher pressure difference between the turbine module inlet $\left(\mathrm{P}_{1}\right)$ and outlet $\left(\mathrm{P}_{2}\right)$ increases the generation head of the dam, the water discharge through the turbine and its electricity generation, in comparison with conventional Bulb plants. This increase in hydropower generation using the kinetic energy of the river during moments of reduced generation heads allows the reduction of the maximum head required to enable the construction of the dam. In addition, it contributes to a high capacity factor, base load type, generation throughout the year. During dry periods, most electricity is generated with potential energy and during wet periods, a considerable amount of electricity is generated by the kinetic energy of the river. 


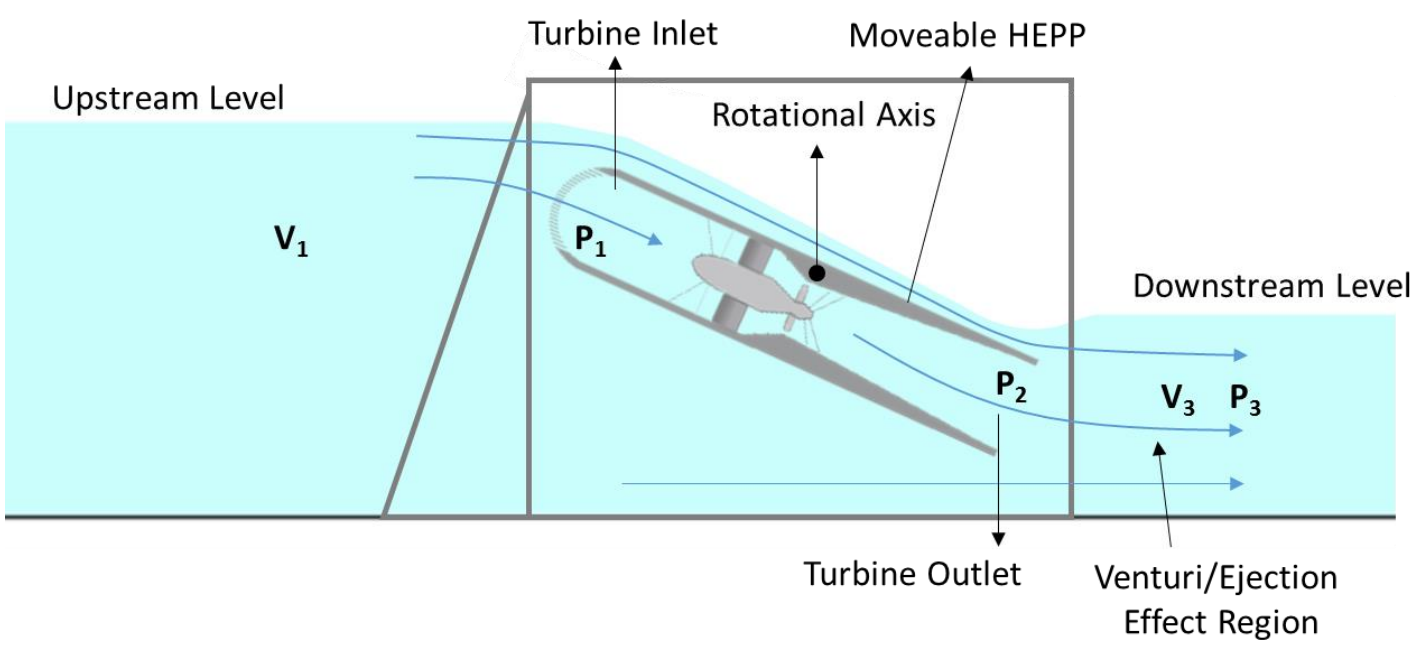

Figure 8: Moveable HEPP operation diagram.

Figure 9 (a) presents the operation of the Moveable HEPP Dam in the Amazon region 330 during the dry periods, with a low water level, which increases the generation head. For instance, 331 the generation head is 16 meters. In this case, the flow to generate electricity is reduced to a minimum. There is not enough flow to generate electricity with all turbines in the dam and there 333 is no water spilled. The majority of the river flow passes through the turbines to optimise 334 electricity generation.

(a)

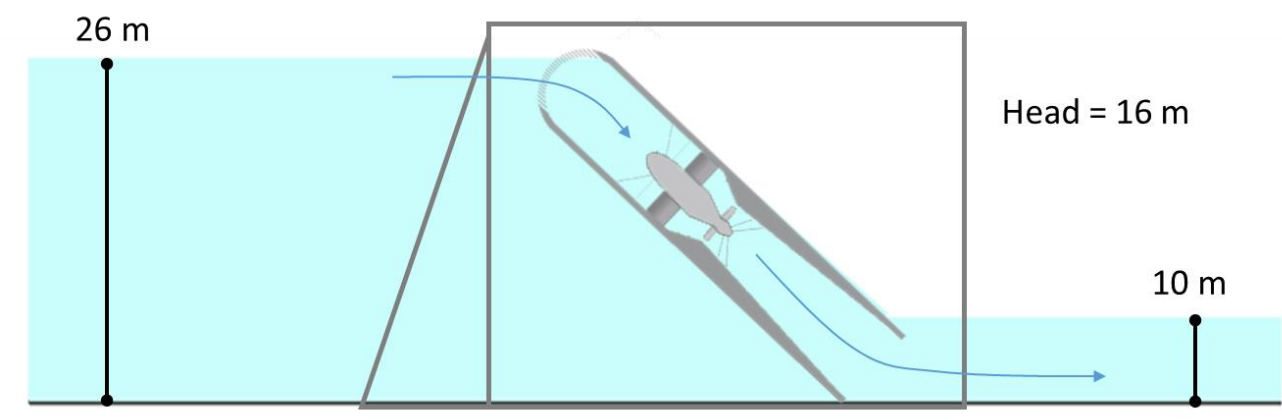

(b)

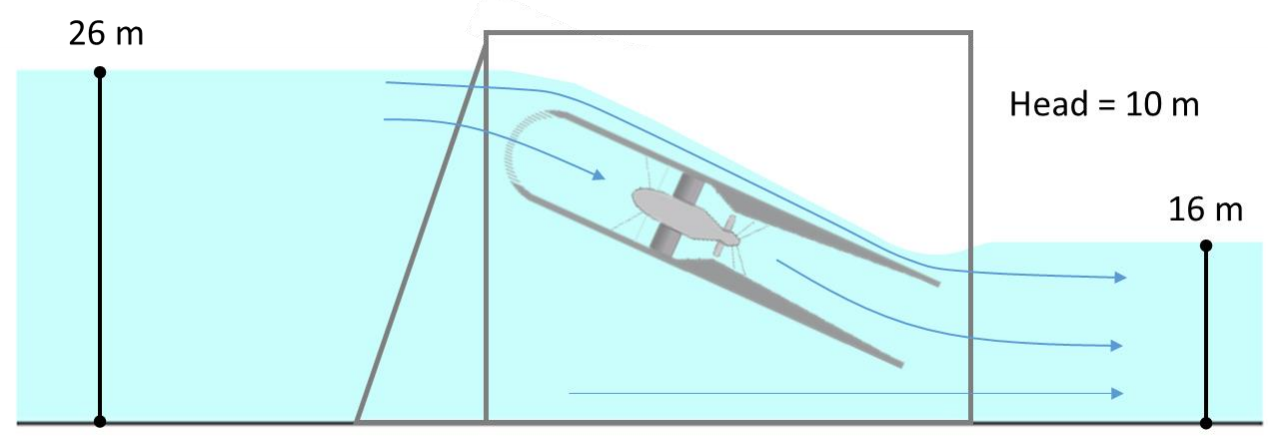


(c)

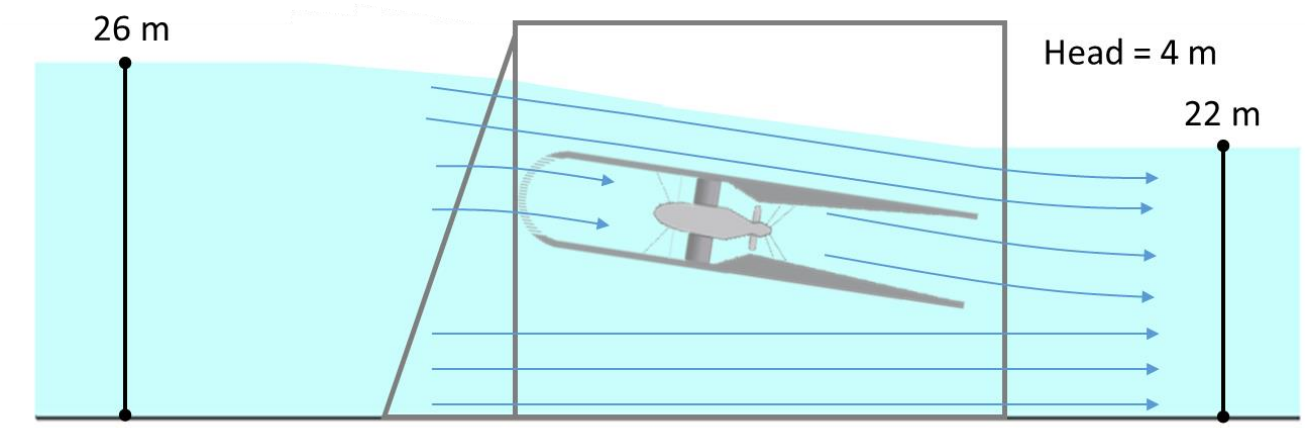

Figure 9: Moveable HEPP in the Amazon region operating (a) during the dry period, (b) during the beginning of the wet period and (c) during the wet period.

Between the dry and wet periods, the water level downstream the Moveable HEPP starts to increase. The generation head is reduced from 16 to 10 meters, as shown in Figure 9 (b). In order to optimize turbine generation, some of the spilled water creates a low-pressure environment after the turbine, which increases the pressure difference between the inlet and outlet of the turbine. It should be noted that it is always preferable to pass the water through the turbines than to spill it.

During the peak of the wet period, as shown in Figure 9 (c), the water level of the river downstream the dam rises even further and the head for hydropower generation is reduced to 4 meters. In addition, the spilled water reaches its maximum and some of the kinetic energy gained in the spilled water is converted into electricity generation due to the venturi effect as explained in Figure 8.

The advantages of the Moveable HEPP, in this example, is that it enables the dam to generate hydropower with a head variation of 16 to 4 meters (in the example). As the dam's height is only 4 meters higher than the highest level of the river during the wet period, the dam's flooded area is very small.

Figure 10 shows a proposal of a large scale Moveable HEPP that could be used to harness low-head hydropower from rivers with large head and level variation. Note that the flooded area above the dam is small, the dam is compact and fits on the riverbed, there is no need for spillways and excess water flows above or below the moveable modules. The moveable module can be produced far from the dam site, reducing construction risk, time and costs. 


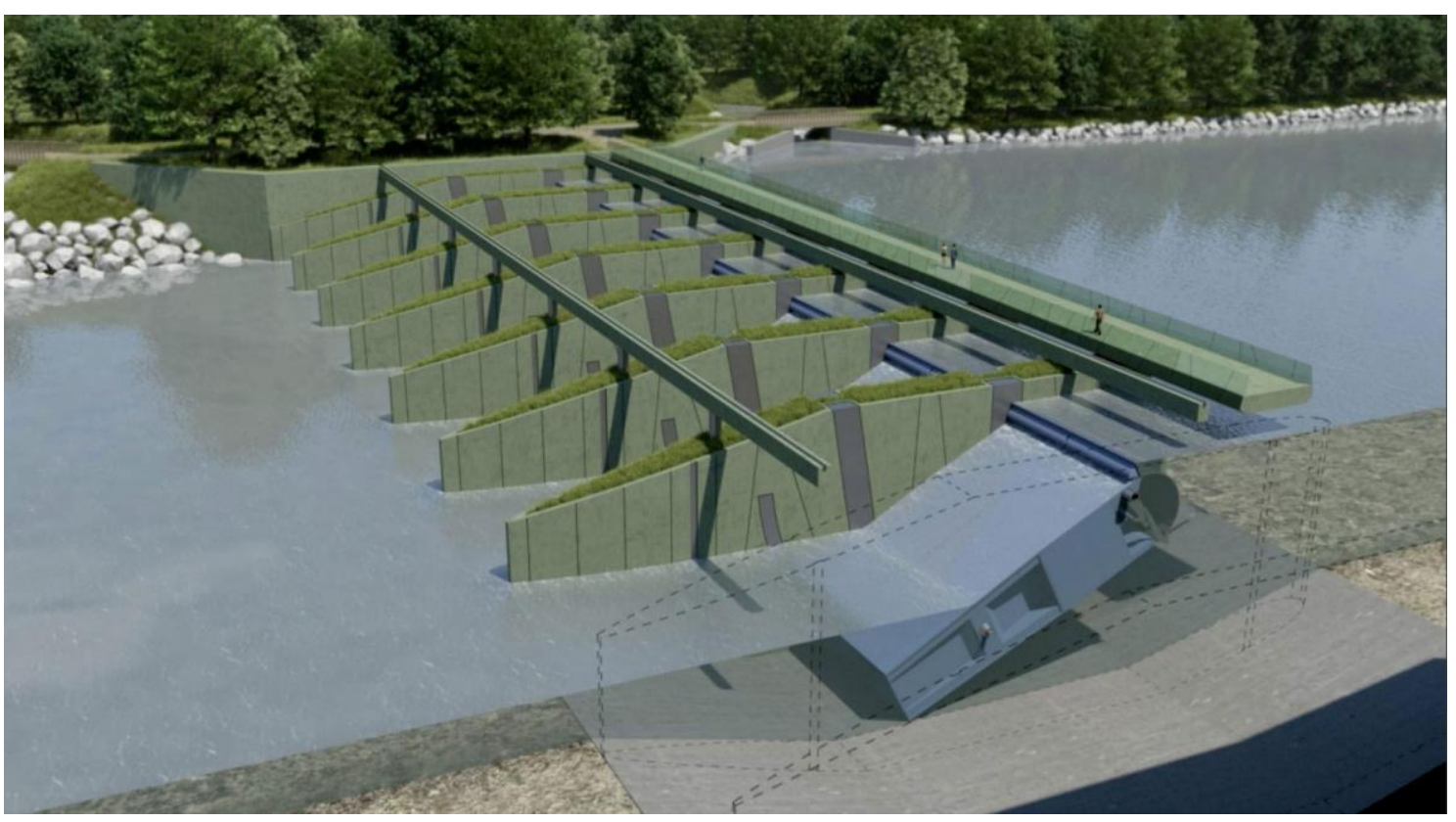

Figure 10: Proposal for a large scale Moveable HEPP [75].

The methodology applied in this study assumes the construction of a head increaser dam similar to the Moveable HEPP concept, with the intent of harnessing the potential and kinetic energy of a river. The total energy generated from the head increaser dam is the sum of the potential energy and the kinetic energy contributions as presented in Equations 1 and 2.

$$
\text { Equation 1: } \quad \text { Total Generation = Potential Energy }+ \text { Kinetic Energy }
$$

Equation 2:

$$
\text { Total Generation }=(h+z) f_{T} g \rho e_{T}
$$

Where:

$h$ - Height difference between the upper reservoir and the lower reservoir (m);

$z$-Contribution of the head increaser effect $(\mathrm{m})$;

$f_{T}-$ Flow that pass through the turbines $(\mathrm{kg} / \mathrm{s})$;

$g$-Acceleration of gravity $\left(9.81 \mathrm{~m} / \mathrm{s}^{2}\right)$;

$\rho$ - Density of water $\left(1,000 \mathrm{~kg} / \mathrm{m}^{3}\right)$;

$e_{T}$ - Low-head dam turbine efficiency (90\%) [34]. 


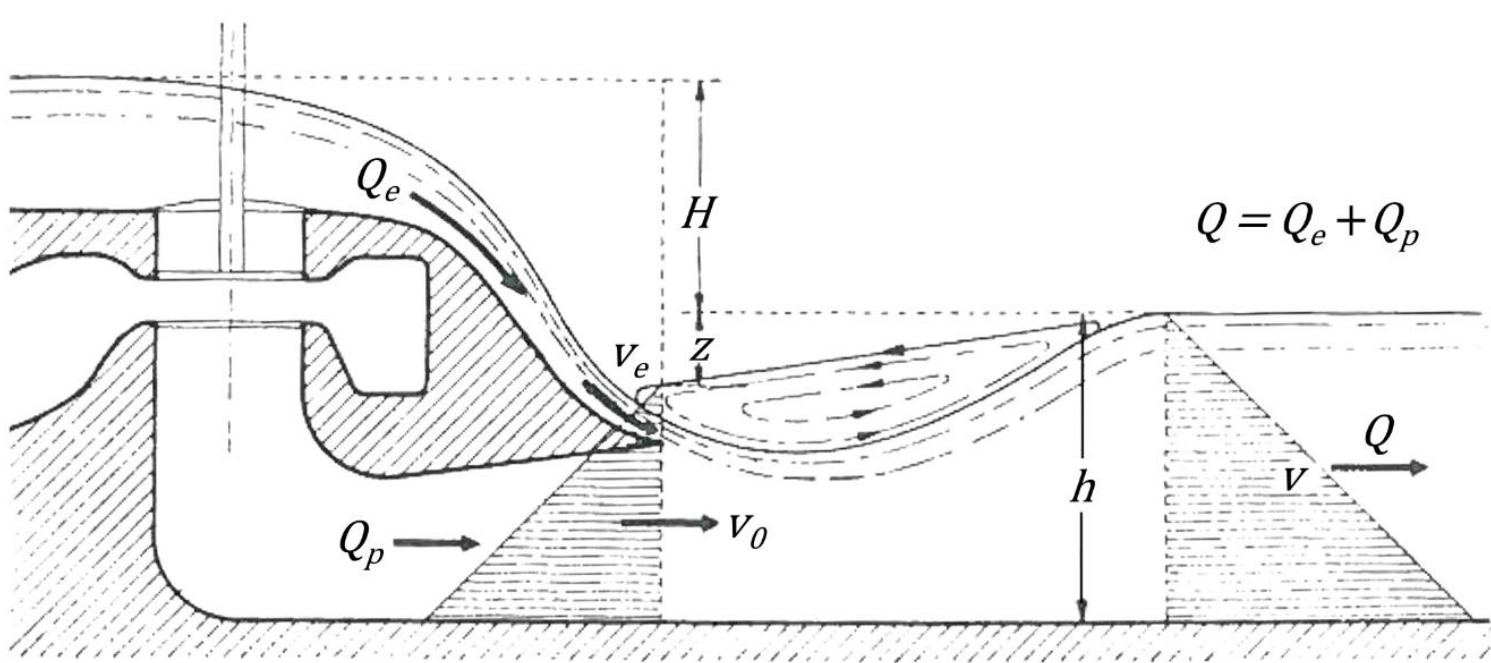

Figure 11: Diagram to estimate the gains from the head increaser effect [34].

The equations and assumed values applied to estimate the gain in head obtainable by the head increaser effect in this paper were taken from Mosonyi 1987 [34]. A series of other approaches and equations for estimating the gains with the head increaser effect are described in [33]. Figure 11 presents the total width $b$ of the outflow i.e. the entire length of the powerhouse. According to the notations presented in Figure 11, the impulse theorem can be represented by Equation 3.

Equation 3: $\quad \gamma b \frac{(h-z)^{2}}{2}+\frac{\gamma}{g} Q_{e} v_{e}+\frac{\gamma}{g} Q_{p} v_{0}=\gamma b \frac{h^{2}}{2}+\frac{\gamma}{g}+Q v$

Where the momentary plant discharge $Q_{p}$, is smaller than the entire plant discharge capacity whenever the head $H$ in question is lower than the design (normal) head. Rearranging terms, we obtain:

Equation 4:

$$
b h\left(-z+\frac{z^{2}}{2 h}\right)=\frac{1}{g}\left(Q v-Q_{e} v_{e}-Q_{p} v_{0}\right)
$$

Compared with $z$, the term $z^{2} / 2 h$ is much smaller and may be neglected for a first estimate, but is added after the first estimate for $z$ is found. Due to friction and impact losses the actual increase will be smaller than that obtained theoretically by applying a reduction coefficient $\mu$. Substituting $b h=Q / v$, the depression of tailwater, i.e. the increase in the effective head upon the runner, is given as:

Equation 5:

$$
z=\mu \frac{v}{g}\left(v_{e} \frac{Q_{e}+Q_{p} \frac{v_{0}}{v_{e}}}{Q}-v\right)
$$

Where:

$\mu$ - Reduction coefficient, determined by model tests and assumed to be 0.9 [34];

$v$ - Mean water velocity in the tailwater after mixing in $\mathrm{m} / \mathrm{s}$ (the actual river flow is assumed [34]); $v_{e}$ - Velocity of the excess spilled flow down the chute in $\mathrm{m} / \mathrm{s}$ (calculated in Equation 6); 
$v_{0}$ - Mean velocity of the water leaving the turbine's draft tube (assumed to be $0.9 \mathrm{~m} / \mathrm{s}$ [34]);

$401 Q_{e}$-Spilled discharge released through the chute in $\mathrm{m}^{3} / \mathrm{s}$;

$402 Q_{p}$ - Discharge released through the turbine in $\mathrm{m}^{3} / \mathrm{s}$;

$Q=Q_{p}+Q_{e}$ - Total discharge passing through the turbine and chute in $\mathrm{m}^{3} / \mathrm{s}$.

404

405

406

407

408

409

410

411

412

413

414

415

416

417

418

419

420

421

422

423

424

425

426

427

428

429

430

431

432

433

434

435

436

Equation 6:

$$
v_{e}=\zeta \sqrt{2 g\left(H+\frac{v_{0}^{2}}{2 g}+z\right)} \quad(\mathrm{m} / \mathrm{s})
$$

Where $\zeta=0.9$ and as $z$ is the unknown variable that needs to be calculated, a first estimate for $v_{e}$ can be make with Equation 7, given that the effective head much higher compared to $z$. After a first estimate of $z$ is found, Equation 6 can be applied for a second iteration to find $z$.

Equation 7: $\quad v_{e}=\zeta \sqrt{2 g\left(H+\frac{v_{0}^{2}}{2 g}\right)} \quad(\mathrm{m} / \mathrm{s})$

The head increaser effect varies mainly with $v_{e}$ and $Q_{e} / Q$. The coefficient $\mu$ varies between close limits and can but slightly be improved by the adequate shaping of the chutes [34]. Mean velocities in the tailrace, $v$, are also fairly constant. The efficiency varies thus directly with the:

a) Head utilized.

b) Relative magnitude of excess flow and the total flow released through the head increaser. Head increasers for run-of-the-river power stations increase the viability of dams with low-head into the range between 1 and $20 \mathrm{~m}$. If the dam's head is higher than 20 meters, focus should be made to increase the number of turbines to make the most use of the hydrological potential in the river. Head increasers should also be considered if flood discharges are significantly in excess of the plant's discharge capacity for three to six months [34]. This is the case of the Amazon River basin, where the generation head is small and where the river flow rate has a highly seasonal pattern. The application of a head increaser will depend on the trade-off between the two points below:

1) Not implement the head increaser effect, so that most of the hydrological potential of the site can be harnessed.

2) Apply the head increase effect, increase the viability of the dam, but lose some of the hydrological potential of the river.

\section{Results}

In order to estimate the power output from a Moveable HEPP on the Amazon region, the location selected was Nova Aripuanã, which is downstream of Santo Antonio Dam in the Madeira River. The river level varies according to 
Figure 12, reaching an average maximum height of 22 meters during April and an average minimum height of 9.5 meters during October. Given a dam height of 26 metres, the generation head varies from 16.5 metres during the dry period to 4 metres during the wet period. The generation head varies 12.5 meters throughout the year. The maximum generation head is 4.1 times higher than the minimum generation head.

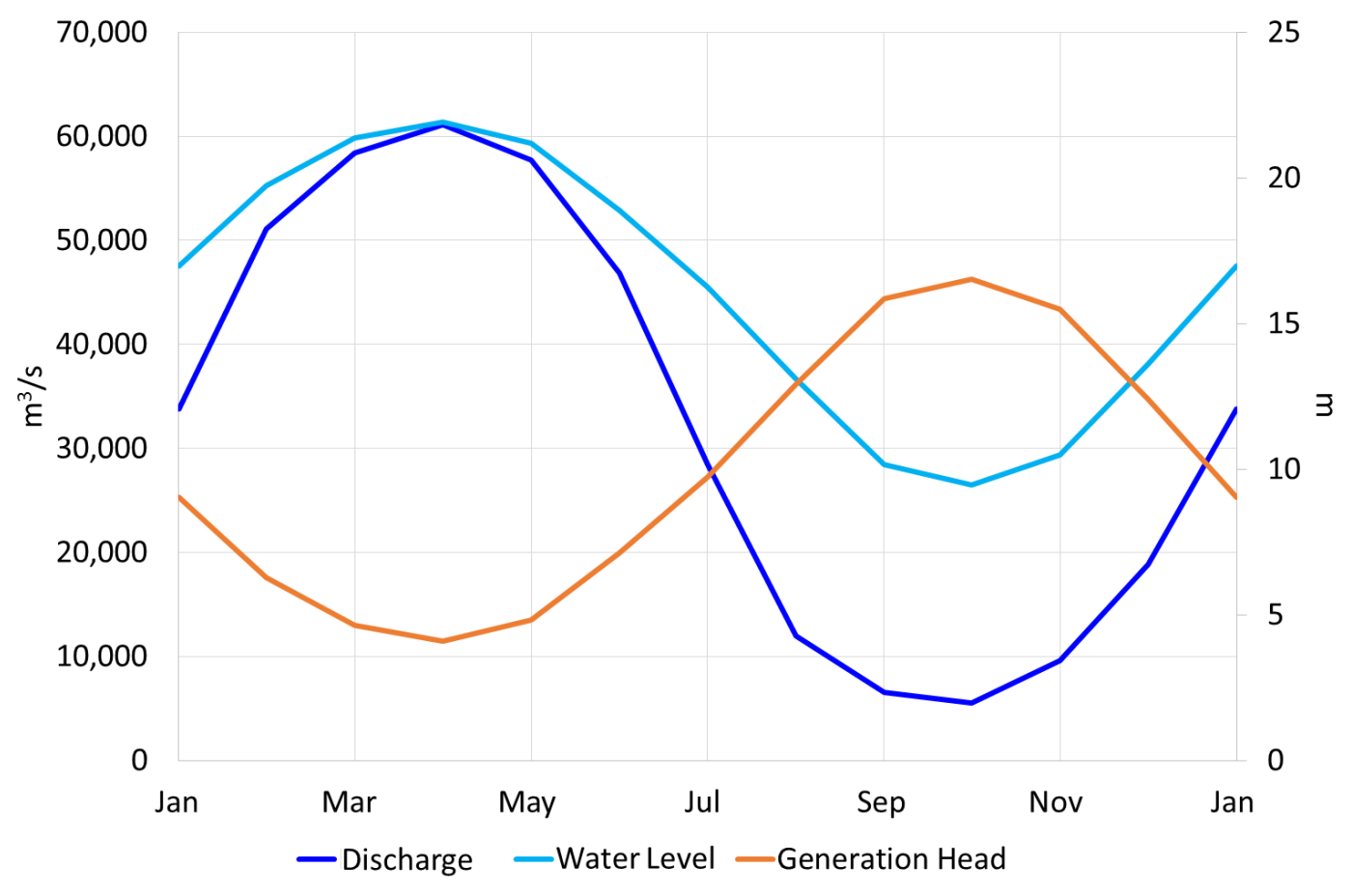

Figure 12: Average river flow (left axis) and level variation, and Aripuanã Dam generation head variation (right axis) [72].

Figure 12 also presents the river discharge variation at Aripuanã. The river flow rate varies from $61,500 \mathrm{~m}^{3} / \mathrm{s}$ during April to $5,500 \mathrm{~m}^{3} / \mathrm{s}$ during October. The maximum river flow is 11.2 times higher than the minimum river flow. It should be noted that the river flow variation is around three times larger than the change in generation head.

The discharge through the turbines at low-heads, without including the head increaser effect, were taken from a tidal barrage design [76] as presented in Table 4. The spillway discharge also does not include the head increaser effect. The head increaser effect, estimated with the equations described in Section 4, contributes to an increase in the turbine discharge and a reduction in the spillway discharge. The contribution from the head increaser effect in the turbine discharge is taken into account as an increase in generation head in the methodology applied in this paper. A series of different arrangement of dams with different number of modules has been analysed and the selected arrangement to be presented in details has 20 Moveable HEPP modules. 
458 Each Moveable HEPP modules can have four or more turbine-generator units, depending on the

459 design of the dam. This estimate assumes a turbine with variable speed and efficiency fixed at

$46090 \%$. The maintenance of high efficiency with a high generation head variability is described in

461 [34]. The results of the equations in Section 4 are presented in Table 4 and Figure 13.

462 Table 4: Aripuanã Moveable HEPP characteristics with and without head increaser effect.

Months Jan Feb Mar Apr May Jun Jul Aug Sep Oct Nov Dec Estimation with 20 Moveable HEPP modules and without head increaser effect

\begin{tabular}{|c|c|c|c|c|c|c|c|c|c|c|c|c|}
\hline River flow $\left(\mathrm{m}^{3} / \mathrm{s}\right)[72]$ & 33,741 & 51,111 & 58,352 & 61,114 & 57,697 & & $20,+11$ & 11,91 & - & , & 9,611 & 18,815 \\
\hline River level (m) [72] & 16.97 & 19.73 & 21.37 & 21.92 & 21.18 & 18.89 & 16.26 & 13.1 & 10.15 & 9.47 & 10.5 & 13.6 \\
\hline Generation head (m) [72] & 9.03 & 6.27 & 4.63 & 4.08 & 4.82 & 7.11 & 9.74 & 12.9 & 15.85 & 16.53 & 5.5 & 12.4 \\
\hline Each module turbined flow $\left(\mathrm{m}^{3} / \mathrm{s}\right)[76]$ & 738 & 695 & 609 & 578 & 620 & 725 & 723 & 582 & 479 & 467 & 487 & 607 \\
\hline Each module spilled flow $\left(\mathrm{m}^{3} / \mathrm{s}\right)$ & 949 & 1,861 & 2,309 & 2,478 & 2,265 & 1,618 & 698 & 17 & - & 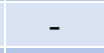 & - & 334 \\
\hline Max. number of modules & 45.7 & 73.6 & 95.9 & 105.8 & 93.1 & 64.6 & 39.3 & 20.6 & 13.6 & 11.7 & 19.7 & 31.0 \\
\hline Max. power generation (MW) & 2,690 & 2,829 & 2,385 & 2,202 & 2,455 & 2,942 & 2,443 & 1,364 & 910 & 800 & 1,315 & 2,060 \\
\hline Numb & 20 & 20 & 20 & 20 & 20 & 20 & 20 & 20 & 14 & 12 & 20 & 20 \\
\hline Powe & 58.8 & 38.5 & 24.9 & 20.8 & 26.4 & 45.5 & 62.1 & 66.3 & 65.0 & 66.6 & 65.8 & 66.4 \\
\hline ith 20 modules (MW) & 1,176 & 769 & 498 & 416 & 527 & 910 & 1,243 & 1,326 & 910 & 800 & 1,315 & 1,329 \\
\hline \multicolumn{13}{|c|}{ Estimation with 20 Moveable HEPP modules and with head increaser effect } \\
\hline$v\left(\mathrm{~m}^{3} / \mathrm{s}\right)$ & 1.21 & 1.65 & 1.83 & 1.90 & 1.81 & 1.54 & 1.08 & 0.66 & 0.53 & 0.50 & 0.60 & 0.83 \\
\hline$v_{\mathrm{e}}-\mathrm{fi}$ & 12.01 & 10.01 & 8.62 & 8.09 & 8.79 & 10.66 & 12.47 & 14.34 & & - & & 14.06 \\
\hline$z-\mathbf{f i 1}$ & 12.45 & 10.74 & 9.45 & 8.96 & 9.62 & 11.32 & 12.82 & 14.36 & - & - & - & 14.27 \\
\hline$z^{2} / 2 h$ & 0.66 & 089 & 0.87 & 0.84 & 0.88 & 0.86 & 0.54 & 0.04 & - & 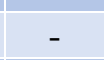 & - & 0.36 \\
\hline$v_{e}-\mathrm{se}$ & 0.02 & 0.06 & 0.08 & 0.09 & 0.08 & 0.05 & 0.02 & 0.00 & - & - & - & 0.01 \\
\hline$z-\sec$ & 0.69 & 0.97 & 0.98 & 0.96 & 0.99 & 0.93 & 0.56 & 0.04 & -5 & - & & 0.37 \\
\hline$z^{2} / 2 h-$ & 0.03 & 0.08 & 0.10 & 0.11 & 0.10 & 0.06 & 0.02 & 0.00 & - & - & - & 0.01 \\
\hline er effect (m) & 0.71 & 1.05 & 1.08 & 1.08 & 1.09 & 0.99 & 0.58 & 0.04 & - & - & - & 0.37 \\
\hline er effect (\%) & 0.07 & 0.14 & 0.19 & 0.21 & 0.18 & 0.12 & 0.06 & 0.00 & - & - & - & 0.03 \\
\hline $\begin{array}{l}\text { Power with } 20 \text { modules inc } \\
\text { increaser effect (MW) }\end{array}$ & 1,269 & 898 & 612 & 526 & 646 & 1,036 & 1,317 & 1,330 & 910 & 800 & 1,315 & 1,369 \\
\hline
\end{tabular}
463

464 Figure 13 shows the estimated generation pattern of the Aripuanã Moveable HEPP 465 throughout the year with 20 modules with $70 \mathrm{MW}$ capacity each, or total capacity of 1,400 MW.

466 The electricity generation pattern has proven to be very interesting. The maximum generation

467 capacity is achieved in July, August, December and January when the river flow and level are not

468 too high or too low as shown in

469 Figure 12. The generation during March, April and May is low because the generation

470 head is considerably reduced. The generation in September and October is also reduced because

471 the river flow is very low. 


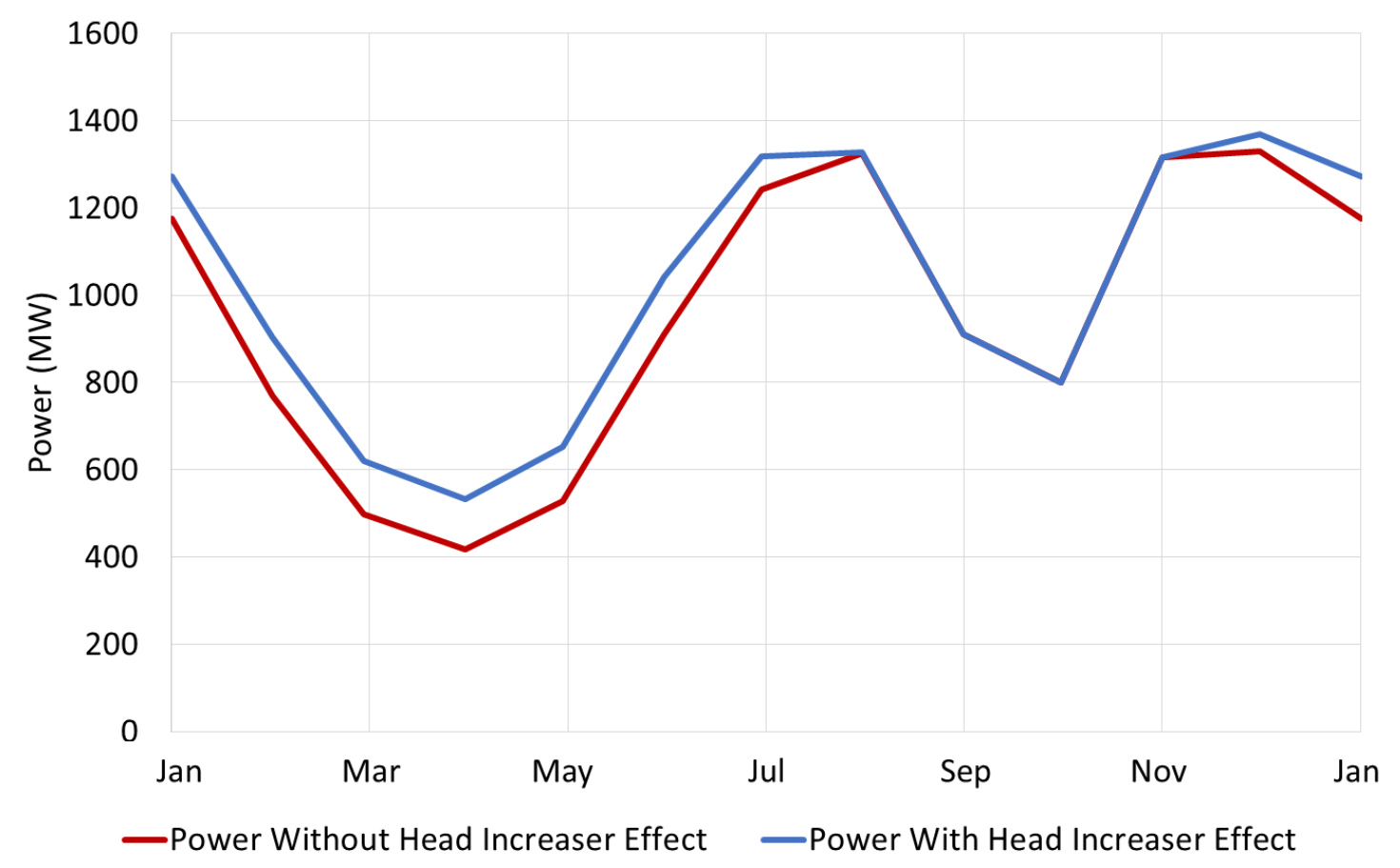

Figure 13: Aripuanã Moveable HEPP power generation with 20 modules and dam height of 26 metres.

Figure 14 (a) presents the estimated hydropower generation output in Aripuanã Moveable HEPP with different numbers of modules and dam height of 26 metres. Similar to Figure 13, the generation reduces during the months of March, April and May due to the low-head generation and reduces during September and October due to the reduction in river flow. Note that, due to the lack of river flow during September and October, the maximum generation during this time is reached with 15 modules. Thus, the dam maximum generation capacity should not exceed much more than 15 modules. The capacity factor of the dam with 10 modules is $78.8 \%, 15$ modules is $76.3 \%, 20$ modules is $71.8 \%, 30$ modules is $61.9 \%$ and 106 modules is $27.7 \%$. It should be noted that the increase in energy generation with the head increaser effect for the dam with 10 modules is up to $23.7 \%, 15$ modules is $22.3 \%, 20$ modules is $20.9 \%, 30$ modules is $18.0 \%$ and 106 modules is $0 \%$ as there is no water spilled. The head increaser effect estimated with equations in Section 4 is underestimated, given that existing prototypes show head increaser efficiencies reach up to 30 to $40 \%[49,48]$. 
(a)

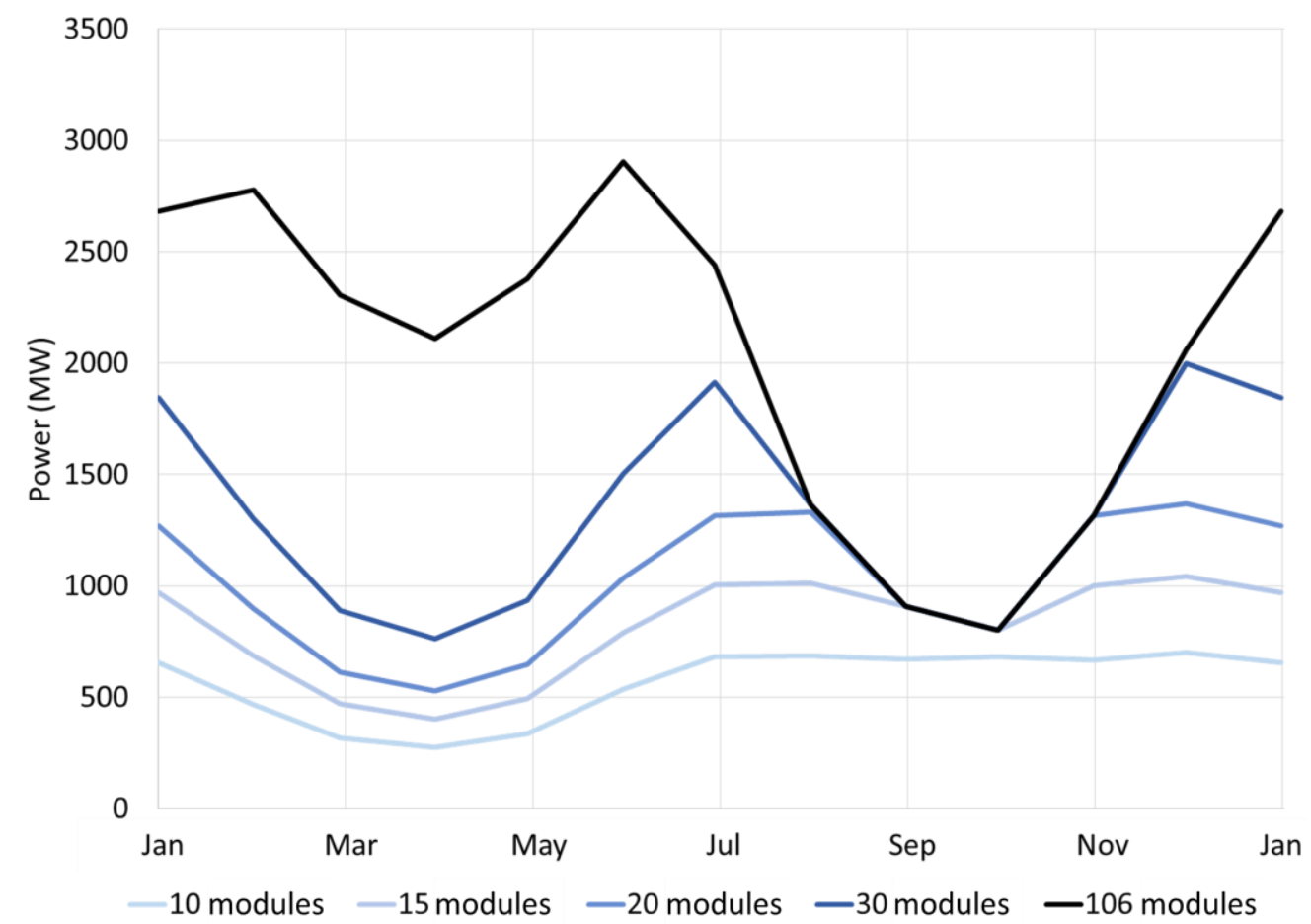

(b)

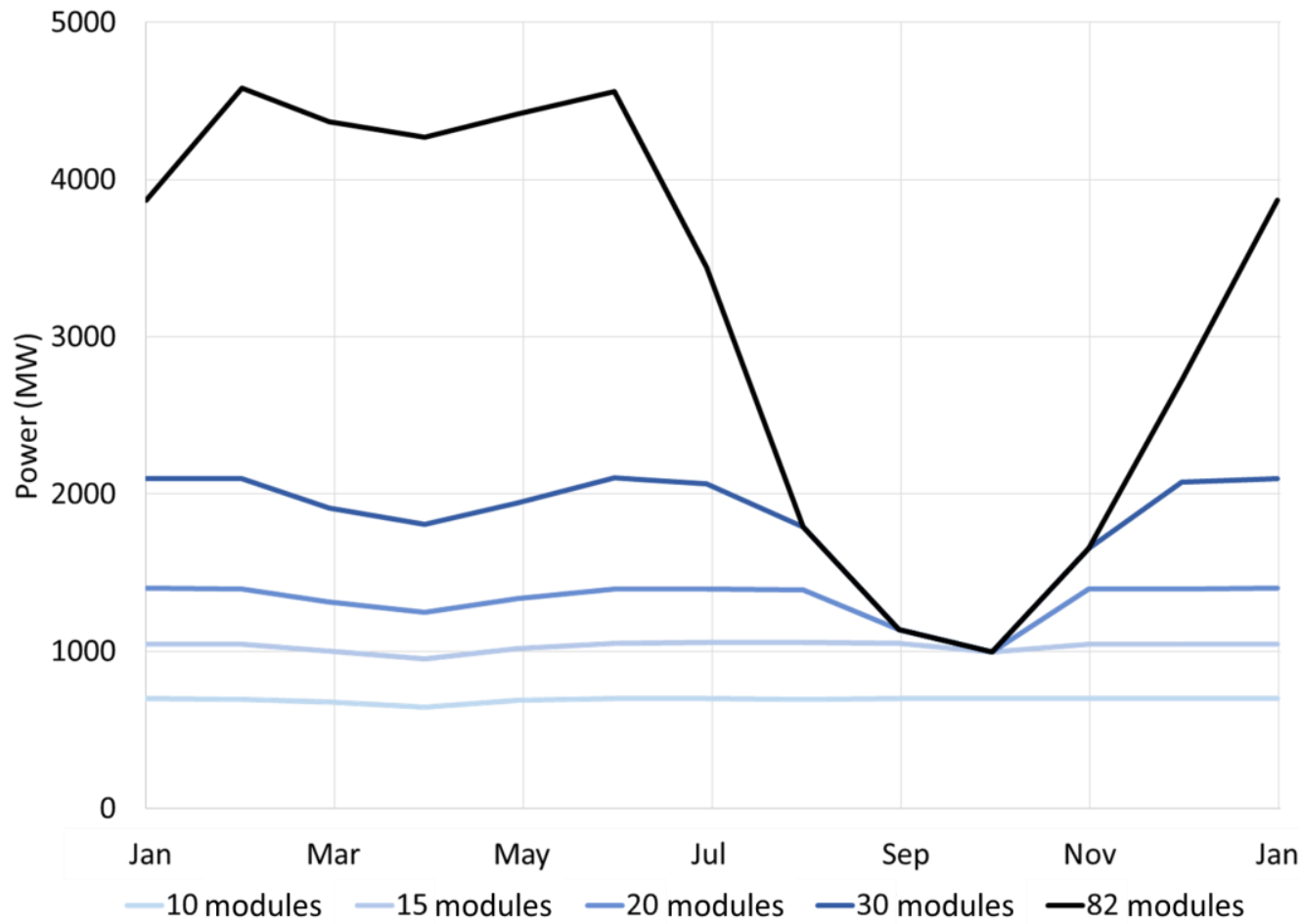

Figure 14: Estimated hydropower generation output in Aripuanã Moveable HEPP with different numbers of modules and dam height of (a) 26 metres and (b) 30 metres.

An alternative to further increase the capacity factor of the power plant is to increase the height of the dam. This will mainly contribute to an increase in generation during the wet period, when the generation head is very low and therefore increase the overall capacity factor of the power plant as presented in Figure 14 (b). Increasing the dam's head in 4 meters, i.e. a final head of 30 meters, the capacity factor of the dam with 10 modules increases to $98.6 \%, 15$ modules 
increases to $98.1 \%, 20$ modules increases to $94.0 \%, 30$ modules increases to $86.0 \%$ and 82 modules increases to $42.9 \%$. The maximum number of modules required to pass all the river flow through the module reduces from 106 to 82 . This is because the module flow increases with the increase in head from 4 to 8 meters. The head increaser effect for the case with 10 modules is up to $17.7 \%$, 15 modules is $16.4 \%, 20$ modules is $15.0 \%$, 30 modules is $12.3 \%$, and 82 modules is $0 \%$ as there is no water spilled.

Amazon dams are located very far from where the electricity would be consumed and transmission costs are high. Thus, the capacity factor of the dam should be high. The proposed dams correspond a good balance between the total hydropower potential of the river and a reasonable capacity factor. The most interesting arrangements for the proposed dam, which have a high capacity factor and a high generation potential, are the dams with a height of 26 meters and 15 to 20 modules or dams with a height of 30 meters with 20 to 30 modules. Another important constraint, which varies with the height of the dam, is the increase in flooded area. The dam with 26 meters would flood an addition area of $104 \mathrm{~km}^{2}$ and the dam with 30 meters would flood an addition area of $987 \mathrm{~km}^{2}$, when compared to the normal yearly flooded area of the river. Given that there is already an excess of hydropower generation in the Amazon region during the wet period with new conventional dams, and that a dam with 30 meters floods a large area, the dam with 26 metres and 20 modules is proposed in this paper.

\section{Discussion}

With the advances in civil and mechanical engineering, the advantages of head increaser dams exceed their disadvantages for low-head dams with highly seasonal flow and level variations. Other suggested conditions for head increasers dam types are proposed below [34]:

1) A river with restricted width, where the enlargement of the bed would encounter difficulties. This happens in very flat regions and in locations where the river is surrounded by a city or a village.

2) The watercourse downstream the proposed site is straight or mildly curved. This is because the dam would result in an increase in velocity of the spilled water, which could cause flooding downstream the river, especially if there is an abrupt deviation on the river flow.

3) If a uniform distribution of hydrological load upon the foundation layers, along the whole width of the riverbed, is required.

4) In case of low-heads, the capacity of the plant should not exceed the medium flow rate since the increase of the number and size of units would reduce the capacity factor of the plant and, thus, jeopardize the economic feasibility of the project.

The Moveable HEPP system brings great benefits to countries that heavily relies on hydropower. This is because its electricity generation pattern is different to conventional 
hydropower dams, in which most of the electricity is generated during the wet period. In the example shown in Figure 13 most of the electricity is generated during July and August. Thus, it could complement the generation from conventional dams and reduce the need for thermoelectric power generation. Another important benefit of this technology is that the flooded area required to build a Moveable HEPP is considerably smaller than in conventional dams. This is because the dam has a height four to eight meters higher than the normal river level during the wet period, which results in a similar flooded area to the river during the wet period. The construction of the dam is also optimised with reduced civil work requirements and the modularity construction approach for the moveable turbines.

Modularity in the construction industry may offer reduced construction time, increased labour productivity and safety, improved manufacturing quality, decreased weather-related delays, reduced environmental and social disturbance, minimized site congestion, lower uncertainty, and increase efficiency. Some disadvantages also exist, including transportation restrictions, reduced flexibility (once modules are fabricated), and higher initial design costs. Constructing components in an off-site manufacturing location leverages a production-oriented environment, including overhead cranes, existing plant equipment, and skilled workers that can be supplemented as needed. Off-site construction may also enable fabrication using diverse materials, which may be difficult in an on-site environment. Often, mechanical equipment is preinstalled within the module before delivery to the site. Although most contractors are familiar with traditional construction techniques, only those experienced in modular-centric industries are likely to be familiar with modularization. Contractors may be hesitant to accept modular approaches without evidence of successful application. However, as modularization represents an increasing share of construction activity, more contractors are becoming aware of its benefits; and financiers are recognizing the reduced financial risk it may offer [38].

Other important aspects that should be optimized in such low-head dams are the substation and transmission line's capacity factors. This is because the dams would be built far from the consumption areas, which require long transmission lines.

These substations, and transmission lines should be used as most as possible. The construction of dams in the Amazon affects the course of the river and should be cautiously planned to have the smallest social and environmental impact possible. For example, the Santo Antônio Dam on the Madeira River is located $5.5 \mathrm{~km}$ upstream Porto Velho city in a straight line. The dam increased the potential energy of the river, where it is located. During the wet period, the spilled water gains considerably more kinetic energy downstream the dam, due to the hydraulic head of around 13 meters. The water with a higher speed is reaching higher altitudes where the course of the river changes abruptly and where Porto Velho is located. This is causing frequent floods in the city and resulting in huge social and economic impacts. Possible solutions to this problems are building more turbines, so that the kinetic energy of the spilled water is 
reduced, alternatively a dam surrounding the city to reduce flooding. Other issues with the operation of dams in the Amazon is the high amount of sediments, specially silt, which considerably increases maintenance costs.

Given that the Aripuanã Moveable HEPP in the Madeira River has a maximum generation head of 16 meters and a generation capacity of 1,400 MW and given the potential for this technology shown in Figure 6. The inclusion of Aripuanã Moveable HEPP systems in the Rivers Juruá, Puru, Solimões, Negro, Iriri and other rivers in the Amazon region, could result in an additional generation capacity of $20 \mathrm{GW}$ to the Brazilian electricity sector.

The Moveable HEPP system could also be used in tidal barriers. In tidal barriers, the moveable module should be designed in a way that the head increaser effect could be used in both directions of the dam. The inclusion of the head increaser effect with the spilled water, gives more operational flexibility to tidal barriers, which allows a considerable increase in its capacity factor and viability.

\section{Conclusion}

This paper presented the past and recent experiences of low-head hydropower generation using the head increaser effect, including its benefits, challenges and debates regarding the technology. It turns out that the technology was not previously economically feasible due to the availability of conventional hydropower potential and the utilization of coal, oil and gas for electricity generation. Nowadays, with the interest of electricity generation with renewable energy sources, as an attempt to reduce global $\mathrm{CO}_{2}$ emissions, and with more restrictive environmental requirements for hydropower developments, the interest in low-head hydropower dams with head increaser effect increased. So far, the most successful technology for dams with head increaser effect is the Moveable HEPP.

The head increasing effect consists of the creation of a sub-pressure environment after the draft tube, which reduced the pressure at the turbine outlet. This results in a higher pressure difference between the turbine inlet and outlet, and increases the water discharge through the turbines, thereby increasing the electricity generation capacity of the turbines.

This article presented a region case study for a large-scale Moveable HEPP system at the Madeira River in the Amazon with the intention to harness the power of rivers with high flow and level variation using a combination of the potential and kinetic energy of the river. The Aripuanã Moveable HEPP was designed with a dam with 26 metres high, which results in a 16 metres maximum generation head, 4 metres minimum generation head and 20 modules with 70 MW each, which sums up to a total generation capacity of 1,400 MW. The capacity factor of the dam 
604 is $72 \%$ and the flooded area is only $104 \mathrm{~km}^{2}$, when compared to the average flooded area of the 605 river during the wet season. The Amazon region has a huge potential for the implementation of 606 Moveable HEPP. It is estimated a total generation capacity of $20 \mathrm{GW}$ on the region from high 607 level and flow variation rivers.

608 In conclusion, low-head hydropower, head increaser dams have been successfully 609 implemented recently and has the potential to become a major source for base-load renewable 610 energy from large head and flow variation rivers in the future.

$611 \quad$ 8. Abbreviations List

612

613 HEPP - Hydro-Electric Power Plant

614 HID - Head Increaser Dam

615

616 9. Acknowledgements

617

We would like to thank CAPES/BRAZIL and IIASA for the research grant and research fellowship, respectively, as part of the CAPES/IIASA Postdoctorate program.

620

10. References

[1] Renewable Energy Policy Network for the 21st Century, "Renewables 2014: Global Status Report," REN21, Paris, 2014.

[2] C. Cherchi, M. Badruzzaman, J. Oppenheimer, C. Bros and J. Jacangelo, "Energy and water quality management systems for water utility's operations: A review," Journal of Environmental Management, vol. 153, pp. 108-120, 2015.

[3] O. Lalitha, "Sustainable development of hydroelectric power - An overview," Water and Energy International, vol. 70, no. 12, pp. 39-43, 2013.

[4] X. Li, S. Guo, P. Liu and G. Chen, "Dynamic control of flood limited water level for reservoir operation by considering inflow uncertainty," Journal of Hydrology, vol. 391, no. 1-2, pp. 124-132, 2010.

[5] A. Ansar, B. Flyvbjerg, A. Budzier and D. Lunn, "Should we build more large dams? The actual costs of hydropower megaproject development," Energy Policy, vol. 69, pp. 43-56, 2014. 
[6] Intergovernmental Panel on Climate Change, "Renewable Energy Sources and Climate Change Mitigation,” IPCC, Geneva, 2012.

[7] "Hydropower: Dimensions of social and environmental coexistence," Renewable and Sustainable Energy Reviews, vol. 12, no. 6, pp. 1588-1621, 2008.

[8] J. Schiffer, H. Benigni, R. Fritsch and H. Jaberg, "Experimental Investigation of the Ejector Effect Utilizable for Vertical Kaplan Turbines,” Wasserwirtschaft, vol. 105, no. 5, pp. 33-39, 2015.

[9] H. Miller, “The STRAFLO Turbine,” Escher Wyss, Zurich, 1974.

[10] Santo Antônio Energia, "Seminário - Grandes Construções," Santo Antônio Energia, São Paulo, 2011.

[11] I. Loots, M. van Dijk, B. Barta, S. van Vuuren and J. Bhagwan, "A review of low head hydropower technologies and applications in a South African context," Renewable and Sustainable Energy Reviews, vol. 50, pp. 1254-1268, 2015.

[12] P. Wiemann, G. Müller and J. Senior, "Review of current developments in low head, small hydropower," in 32nd IAHR Conference, Venice, 2007.

[13] S. Heimerl and B. Kohler, "Kleinwasserkraft-Konzepte: Hydraulische Strömungsmaschinen für kleine Durchflüsse und niedrige Fallhöhen,” ElectroSuisse, Fehraltorf, 2014.

[14] Voith, "StreamDiverTM," Voith, 2017. [Online]. Available: http://www.voith.com/en/products-services/hydropower/streamdiver-55362.html.

[15] B. Brinkmeier and M. Aufleger, "Fließgewässerkraftwerke zur Wasserkraftnutzung an ökologisch sensiblen Standorten,” Wasserwirtschaft, Vols. 7-8, pp. 37-41, 2011.

[16] D. Innerhofer, J. Lochschmidt, J. Lampl, R. Wührer, B. Brinkmeier and M. Aufleger, “Anströmung von Kompaktturbinen,” Wasser und Abfallw, vol. 67, p. 307-314, 2015.

[17] F. Rourke, F. Boyle and A. Reynolds, “Tidal energy update 2009," Applied Energy, vol. 87, no. 2, pp. 398-409, 2010.

[18] J. González-Caballín, E. Álvarez, A. Guttiérrez-Trashorras, A. Navarro-Manso, J. Fernández and E. Blanco, "Tidal current energy potential assessment by a two dimensional computational fluid dynamics model: The case of Avilés port (Spain)," Energy Conversion and Management, vol. 119, pp. 239-245, 2016.

[19] V. Ramos and G. Iglesias, "Performance assessment of Tidal Stream Turbines: A parametric approach,” Energy Conversion and Management, vol. 69, pp. 49-57, 2013.

[20] J. Riglin, C. Daskiran, J. Jonas, C. Schleicher and A. Oztekin, "Hydrokinetic turbine array characteristics for river applications and spatially restricted flows," Renewable Energy, vol. 97 , pp. 274-283, 2016. 
[21] M. Tahani, N. Babayan, F. Astaraei and A. Moghadam, "Multi objective optimization of horizontal axis tidal current turbines, using Meta heuristics algorithms," Energy Conversion and Management, vol. 103, pp. 487-498, 2015.

[22] A. Mesquita, A. Mesquita, F. Palheta, J. Vaz, M. Morais and C. Gonçalves, "A methodology for the transient behavior of horizontal axis hydrokinetic turbines," Energy Conversion and Management, vol. 87, pp. 1261-1268, 2014.

[23] S. Barbarelli, M. Amelio, T. Castiglione, G. Florio, N. Scornaienchi, A. Cutrupi and G. Lo Zupone, "Analysis of the equilibrium conditions of a double rotor turbine prototype designed for the exploitation of the tidal currents," Energy Conversion and Management, vol. 87, pp. 1124-1133, 2014.

[24] A. Fernandes and A. Rostami, "Hydrokinetic energy harvesting by an innovative vertical axis current turbine," Renewable Energy, vol. 81, p. 694-706, 2015.

[25] S. Sharma and R. Sharma, "Performance improvement of Savonius rotor using multiple quarter blades - A CFD investigation," Energy Conversion and Management, vol. 127, pp. 43-54, 2016.

[26] L. Wang, L. Zhang and N. Zeng, "A potential flow 2-D vortex panel model: Applications to vertical axis straight blade tidal turbine," Energy Conversion and Management, vol. 48, no. 2, pp. 454-461, 2007.

[27] J. Schiffer, H. Benigni, H. Jaberg and R. G. J. Fritsch, "Numerical and Experimental Investigation of the Ejector Effect Applicable to Low Head Vertical Kaplan Turbines," in Conference on Modelling Fluid Flow, September 1-4, Budapest, 2015.

[28] M. Kuschke and K. Strunz, "Modeling of tidal energy conversion systems for smart grid operation," in IEEE Power and Energy Society, Detroit, 24-28 July, 2011.

[29] Eletronorte, "Desenvolvimento de Cabeça de Série de Unidade Hidrocinética para Aproveitamento de Potencial Jusante de Usina Hidrelétrica,” Eletronorte, Brasilia, 2016.

[30] power-technology.com, "Hastings Hydrokinetic Power Station," [Online]. Available: http://www.power-technology.com/projects/hastingshydrokinetic/. [Accessed 28 March 2016].

[31] D. Kumar and S. Sarkar, "A review on the technology, performance, design optimization, reliability, techno-economics and environmental impacts of hydrokinetic energy conversion systems," Renewable and Sustainable Energy Reviews, vol. 58, pp. 796-813, 2016.

[32] N. Laws and B. Epps, "Hydrokinetic energy conversion: Technology, research, and outlook," Renewable and Sustainable Energy Reviews, vol. 57, pp. 1245-1259, 2016. 
[33] S. Slisskii, Ejection into Tailraces of Hydropower Plants, Jerusalem: Israel Program for Scientific Translations, 1953.

[34] E. Mosonyi, Water Power Development: Low-Head Power Plants, Budapest: Akadémiai Kiadó, 1987.

[35] Life Nature, "LIFE and Freshwater Fish,” European Commission, Luxembourg, 2015.

[36] R. Siegel, "Head Augmentation in Hydraulic Turbines by Means of Draft Tube Ejectors. Master's Thesis," Virginia Polytechnic Institute and State University, Virginia, 1982.

[37] S. Kerr, "The Moody Ejector Turbine," in American Society of Mechanical Engineers, No. 1828, pg 1201-1217, Pennsylvania, 1921.

[38] T. Smith, et al., "A Multi-Year Plan for Research, Development, and Prototype Testing of Standard Modular Hydropower Technology,” Oak Ridge National Laboratory, Oak Ridge, 2017.

[39] C. Herschel, “The Fall-Increaser,” Harvard Engineering Journal, Cambridge, 1908.

[40] D. Brandl, "The Economics of Small Hydro," Water Power 81 - U.S Army Corps of Engineers, vol. 2, pp. 947-963, 1981.

[41] W. Hickman, "DOE Small Hydropower Program," American Society of Mechanical Engineers, New York, 16-21 November, pp. 16-21, 1980.

[42] M. Replogle, "Unique Hydraulic Power Plant at the Henry Ford Farms," Transactions of the ASME, pp. 1043-1064, 1915.

[43] J. Sirnir, "New Development in Hydroelectric Power-Plant Design," in American Society of Mechanical Engineers, Atlanta, 1922.

[44] O. Thurlow, "Backwater-suppressing type of hydroelectric plant". USA Patent US1606978 A, 16 November 1926.

[45] N. Kovalev, Hydroturbines: Design and construction, Washington: Israel Program for Scientific Translations, 1965.

[46] Life Environment, "Best LIFE Environment projects 2011," European Commission, Luxembourg, 2012.

[47] Hydro-Energie Roth GmbH, "Abschlussbericht zur Entwicklung einer neuartigen beweglichen, über- und unterströmbaren Wasserkraftanlage," Deutsche Bundesstiftung Umwelt, Rodenbach, 2003.

[48] Deutsche Bundesstiftung Umwelt, "Das bewegliche Wasserkraftwerk,” DBU, Osnabruck, 2012.

[49] Zek, "Ejektor-Kraftwerk an der YBBS," 2017. [Online]. Available: http://www.zek.at/hydro/news/wirtschaftliche-stadtwehr/print. 
[50] Elektrizitätswerk Mittelbaden Wasserkraft GmbH, "Das Bewegliche Wasserkraftwerk," Elektrizitätswerk Mittelbaden Wasserkraft GmbH, 2017. [Online]. Available: http://www.das-bewegliche-wasserkraftwerk.de/index 1f36.html.

[51] Hydro-Energie Roth GmbH, "Das bewegliche Wasserkraftwerk," Hydro-Energie Roth, 2017. [Online]. Available: http://www.hydroenergie.de/bewegliche-wka.

[52] International Commission for the Protection of the Danube River, "Hydropower Case Studies and Good Practice Examples," ICPDR, Vienna, 2013.

[53] LIFE Environment, "LIFE and Climate Change Mitigation," European Commission, Luxembourg, 2015.

[54] I. Böckmann, B. Lehmann, A. Hoffmann and M. Kühlmann, "Fischabstieg: Verhaltensbeobachtungen vor Wanderbarrieren," in Wasser, Energie und Umwelt, Berlin, Springer, 2017, pp. 417-428.

[55] M. Aufleger and B. Brinkmeier, "Wasserkraftanlagen mit niedrigen Fallhöhen Verschiedene Konzepte im kritischen Vergleich," Österreichische Wasser- und Abfallwirtschaft, vol. 67, pp. 281-291, 2015.

[56] T. Pohjamo, "Fishway system with turbine". USA Patent US6325570 B1, 04 December 2001.

[57] HSI Hydro Engineering GmbH, "Die bewegliche Wasserkraftanlage," HSI Hydro, 2015. [Online]. Available: https://www.hsihydro.de/en/die-bewegliche-wasserkraftanlage/.

[58] Bayerische Landeskraftwerke GmbH, "Ökologische Wasserkraft," Bayerische Landeskraftwerke, $2017 . \quad$ [Online]. Available: https://www.landeskraftwerke.de/kraftwerkstypen.htm.

[59] OSSBERGER, "Enclosed Pivoting Kaplan: Power from a submerged hydro turbine for fishery sensitive rivers," OSSBERGER, Weißenburg, 2010.

[60] K. Drack, "Effizienzsteigerung bei Kleinwasserkraftwerken durch Nutzung der "Ejektorwirkung“" am Beispiel Mühltalwehr," Firmenschrift der K. u. F. Drack GmbH \& Co. KG. Scharnstein, 2007.

[61] R. Fritsch, J. Schiffer and R. Fritsch, "Ejektorwirkung bei Überwasser mit Vertikaler Kaplan-Turbine," Wasserwirtschaft, vol. 10, pp. 32-35, 2015.

[62] R. Gruber, "Ejektor-Kraftwerk macht Standort an der Ybbs wirtschaftlich," ZEK-Hydro, vol. 5, pp. 14-17, 2013.

[63] M. Witting, "Der Fallhöhenmehrer," Institut für Infrastruktur Arbeitsbereich für Wasserbau, Innsbruck, 2010. 
[64] K. Dezelak, J. Pihler and G. Stumberger, "Possibilities for small hydropower plant construction in the old bed of the river Drava," in International Conference on Renewable Energies and Power Quality, 8-10 of April, Cordoba, 2014.

[65] R. Prenner, F. Florez and W. Troy, "Rehabilitation and Refurbishment of an Intake Weir of a Diversion-Type Run-Of River Plant," Annual of the University of Architecture, Civil Engineering and Geodesy - Sofia, vol. 50, no. 1, pp. 23-34, 2017.

[66] S. Rost, D. Gerten, A. Bondeau, W. Lucht, J. Rohwer and S. Schaphoff, "Agricultural green and blue water consumption and its influence on the global water system," Water Resources Research, vol. 44, pp. 1-17, 2008.

[67] S. Hempel, K. Frieler, L. Warszawski, J. Schewe and F. Piontek, "A trend-preserving bias correction-the ISI-MIP approach,” Earth System Dynamics, vol. 4, no. 2, pp. 219-236, 2013.

[68] C. Michailovsky, S. McEnnis, P. Berry, R. Smith and P. Bauer-Gottwein, "River monitoring from satellite radar altimetry in the Zambezi River basin," Hydrology and Earth System Sciences, vol. 16, p. 2181-2192, 2012.

[69] C. Yuan, P. Gong, H. Zhang, H. Guo and B. Pan, "Monitoring water level changes from retracked Jason-2 altimetry data: a case study in the Yangtze River, China," Remote Sensing Letters, vol. 8, no. 5, p. 399-408, 2017.

[70] C. Birkett, "Contribution of the TOPEX NASA radar altimeter to the global monitoring of large rivers and wetlands," Water Resources Research, vol. 34, no. 5, pp. 1223-1239, 1998.

[71] F. Papa, F. Frappart, Y. Malbeteau, M. Shamsudduha, V. Vuruputur, M. Sekhar, G. Ramillien, C. Prigent, F. Aires, R. Pandey, S. Bala and S. Calmant, "Satellite-derived surface and sub-surface water storage in the Ganges-Brahmaputra River Basin," Journal of Hydrology: Regional Studies, vol. 4, p. 15-35, 2015.

[72] SNIRH, "HIDROWEB," National Water Resources Information System, [Online]. Available: http://www.snirh.gov.br/hidroweb/. [Accessed 12 March 2016].

[73] R. Nave, "Venturi Flowmeter," HyperPhysics, 09 November 2016. [Online]. Available: http://hyperphysics.phy-astr.gsu.edu/hbase/Fluids/venturi.html.

[74] G. Doig, "Transonic and supersonic ground effect aerodynamics," Progress in Aerospace Sciences, vol. 69, pp. 1-28, 2014.

[75] EU - LIFE, E-Werk Mittelbaden and Hydro-Energie Roth GmbH, "The moveable hydro electric power plant (Hepp)," EU - LIFE, Luxembourg, 2012.

[76] J. Xia, R. Falconer, B. Lin and G. Tan, "Estimation of annual energy output from a tidal barrage using two different methods," Applied Energy, vol. 93, pp. 327-336, 2012. 
